\title{
Geographic Clustering and Productivity: An Instrumental Variable Approach for Classical Composers
}

\author{
Karol Jan Borowiecki
}

TEP Working Paper No. 0611

March 2011

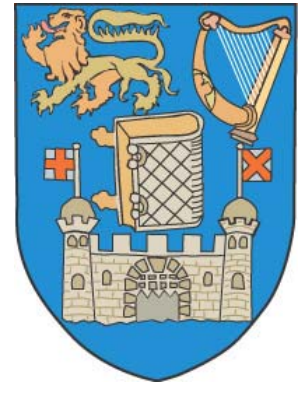

Trinity Economics Papers

Department of Economics

Trinity College Dublin 


\title{
Geographic Clustering and Productivity: An Instrumental Variable Approach for Classical Composers
}

\author{
Karol Jan Borowiecki \\ Trinity College Dublin and University of Southern Denmark
}

July 2012

\section{$\underline{\text { ABSTRACT }}$}

It is difficult to estimate the impact of geographic clustering on productivity because of endogeneity issues. I use birthplace-cluster distance as an instrumental variable for the incidence of clustering of prominent classical composers born between 1750 and 1899. I find that geographic clustering causally impacts productivity: composers were writing around one additional influential work every three years they spent in a cluster. The best composers and those who migrated to Paris appear to be the greatest beneficiaries of clustering. Placebo tests disclose that the effects are attributable to locating in contemporaneous cluster cities, as opposed to historical cluster locations or large cities in general.

Keywords: geographic concentration, cities, mobility, productivity, urban history, composer

JEL Classifications: D24, J24, J61, N90, O47, R11, Z19

\footnotetext{
This research has been awarded the ACEI Presidents' Best Paper Award (Copenhagen, 2010) and the First Place Award in the Poster Session during the European Science Days (Steyr, 2009). The author wishes to thank Jeremiah Dittmar, Benjamin Elsner, Victor FernandezBlanco, Tim Fry, Andrius Kazukauskas, Cormac O'Grada, John O'Hagan, Kevin O'Rourke, Andrew Oswald, Juan Prieto-Rodriguez, William Strange, Fabian Waldinger, anonymous referees and participants at the European Science Days, Irish Society of New Economists Conference, Ruhr Graduate School Conference, Scottish Economic Society Conference, Association for Cultural Economics International Conference, Warsaw International Economic Meeting, European Economics Association Congress, European Workshop in Applied Cultural Economics, Economic History Society Conference, Spanish Economics Society Symposium, Royal Economic Society Conference, invited seminar at the universities of Zurich, Oviedo, Southern Denmark and Paris North. The author acknowledges the excellent research assistance provided by Jean Acheson and James Walsh, and a generous research fund provided by John O'Hagan.

Contact: Trinity College Dublin, Department of Economics, Dublin 2, Ireland. E-Mail: borowiek@tcd.ie.
} 


\section{Introduction}

The most productive individuals or firms are often located in geographic clusters. In locations with a high concentration of like agents, some evidence shows that workers earn more (e.g. Glaeser and Mare, 2001), firms perform better (e.g. Nickell, 1996) and visual artists peak earlier (Hellmanzik, 2010). Knowledge on causality is however still limited. Are geographic clusters attracting the most productive or are individuals and firms who cluster more productive because of positive externalities associated with cluster locations? In other words, is self-selection driving the empirical evidence on better performance in geographic clusters, or does there exist a clustering benefit? This question is of considerable importance not only for individuals or firms that are located in geographic clusters, but also for policymakers who try to replicate the success stories of clusters such as Silicon Valley and create, for example, special economic zones in their regions. However, without knowledge of the causal relationship between clustering and productivity, intervention can cause harmful distortions to the market (Desrochers and Sautet, 2004).

There is a large body of literature that highlights the association between geographic clustering (or more in general - urban agglomeration) and productivity (see Rosenthal and Strange, 2004, for a review). However, the existing literature does not always adequately address the endogeneity of clustering to productivity and thus does not convincingly establish a causal relationship. Apart from endogeneity issues, omitted variables (e.g. quality of local infrastructure) may drive both clustering and economic outcomes, producing misleading estimates. A further problem arising is that workers (or firms) are not homogeneous and therefore aggregation might produce imprecise results (Glaeser and Mare, 2001). Ciccone and Hall (1996) tackled first the endogeneity problems and have used lagged instruments (e.g. population in previous century). However, if aggregated data series are used it is not possible to control for heterogeneous effects of individuals.

This study addresses both identification issues. The analysis is based on a unique individual-level data set and employs valid individual-based instruments to account for endogeneity and omitted-variable bias. It uses exogenous geographic birthplace-cluster distance as an instrumental variable for the incidence of clustering in order to estimate the impact of locating in geographic clusters on productivity. The instrumental variable method makes it credible to assert that the association between clustering and productivity is a causal relationship rather than simply a correlation. Geographic distance can be an important determinant for location choice in historical periods when traveling was constrained. I therefore chose for the analysis the period roughly associated with the beginnings and 
duration of the industrial revolution. In the late $18^{\text {th }}$ and $19^{\text {th }}$ centuries, due to technological inventions such as the railway or the steamboat, travelling was facilitated, however still very expensive in terms of time and price (see Clark, 2007). ${ }^{2}$

This paper focusses, for several reasons, on only one specific group of individuals, namely classical composers. First, as argued by O’Hagan and Borowiecki (2010), composers were highly mobile individuals with a marked need to cluster in order to exploit economies of scale. Composers needed either a symphony orchestra or opera company and the complementary infrastructure, such as concert hall or opera house, in order to perform and test their compositions. Second, composers in the period analyzed were independent artists with a remarkable entrepreneurial drive (Scherer, 2001). They became market oriented and can be regarded as producers who supply cultural goods (new compositions) and provide certain services, such as teaching, organising tours, performing etc. (Borowiecki, 2012). Third, the period encompasses many of the most influential composers hence data are relatively well available and reliable. A further implicit advantage of the period chosen is that it covers only deceased individuals hence a study of whole life-time output becomes possible.

The data set employed is extracted from large music dictionaries and it covers the life histories of a global sample of 116 prominent classical composers born between 1750 and 1899. The picture emerging indicates that in the period analyzed Paris was the predominant geographic cluster for classical music, followed by Vienna and London. Instrumenting for the incidence of clustering I explore the causal relationship between locating in a cluster and productivity measured by the number of significant compositions. The findings suggest a high and positive cluster effect on composers' productivity who located in one of the geographic clusters studied (i.e. Paris, Vienna or London). As a result of the positive externalities associated with geographic clusters, the evidence shows that composers have written approximately one additional work every three years. The results are robust to a large number of tests, including two falsification exercises, in which I study the impact of locating in large cities that are not clusters for classical composers or cities that have been clusters in the past but are not anymore in the period studied. Further, I find heterogeneity in the returns: productivity gain of the top composers is even higher and reached 1.5 additional works per annum. Productivity of composers who migrated to Paris (as opposed to being born in the French capital) increased their output by almost one additional work every two years. Finally, this analysis looks at composers' overall lifetime accomplishments and implies that the

\footnotetext{
${ }^{2}$ In the Identification Section further evidence is provided on how geographic distance markedly determines location choice in historical time periods while decreasing in importance more recently.
} 
positive agglomeration externalities can be persistent over long periods of time. While the results are very interesting, given the limited nature of the data employed, it needs to be pointed out that they are tentative and hence mainly suggestive.

Given the finding that migrant individuals can be major beneficiaries of clustering, this study relates also to the elite migration literature (see Commander et al., 2004, for review). The migration of skilled individuals is regarded to be costly for the sending country, because of lost investment in education, high fiscal costs and labor market distortions. Individuals who migrate must thus experience a sufficiently higher benefit in order to cover the associated cost of moving. Nevertheless usually research 'cannot adjudicate on whether migration improves (...) productivity' (Hunter et al., 2009). This article relates also to cultural economics research. Several recent studies demonstrated remarkable clustering intensity of visual artists (O’Hagan and Hellmanzik, 2008) or classical composers (O’Hagan and Borowiecki, 2010). The authors explain the observed clustering patterns and speculate as to the existence of positive externalities associated with geographic clusters. In this article an empirical test of those hypotheses is provided. The results provide important contributions that fill a gap in both strands of the literature.

The remainder of this article is organized as follows. The next section, provides an overview of the theory on externalities associated with geographic clusters and discussed the possible mechanisms for this. The third section describes the data. In the fourth section, the identification strategy is discussed, in the fifth section the empirical findings are presented, and the last section provides concluding remarks.

\section{The Mechanism}

In the following, I describe how locating in a geographic cluster can impact composers' productivity. I briefly outline three formal theories of a benefit associated with geographic clustering, as outlined in Glaeser et al. (1992), apply the arguments to the case of classical composers and provide anecdotal evidence.

The cost of transmitting knowledge rises with distance. Therefore, geographic proximity is argued to facilitate spillover effects between firms in an industry (e.g. Marshall, 1890). The theory should apply also to creative industries and classical music composition. In cities with a particularly high concentration of composers, when some kind of face-to-face contact between artists is enabled, synergies and spillovers may positively impact the 
individual's ability to innovate. ${ }^{3}$ Historical archives assert that close contact and collaboration between prominent composers was common. For example, informal gatherings were repeatedly hosted by colleagues or friends, as recorded in a letter from Carl Kragen to his friend - Robert Schumann (1810-1856):

Tomorrow (...) [Franz] Liszt [1811-1886] is to play at our house with [Karol] Lipinski [1790-1861]! Do come for it! Ah, if you could only induce [Felix] Mendelssohn [1809-1847] and his wife to come too! (Letter of 27 March 1840)

With geographic proximity many professional or private relationships were formed. Among all the composers and musicians Franz Liszt met during his career, his friendship with Hector Berlioz (1803-1869) holds an exceptional place. The relationship between the two towering figures of the musical and cultural world of their time began during Berlioz's first performance of Symphonie Fantastique (1830) at the Paris Conservatoire in France. In London - a further geographic cluster - Berlioz met Richard Wagner (1813-1883). The German composer recollects the encounter as well as his first impression of his new colleague's composition skills as follows:

When five years ago destiny brought us closer together in London, I boasted of having an advantage over you: I could understand and appreciate your works perfectly, while you could only get an imperfect idea of mine because of your lack of knowledge of the German language, to which my dramatic conceptions are so closely bound. (Letter of 22 February1860)

The second theory advocating a clustering benefit is posited by Porter (1990). In Porter's view, the local competition in specialized, geographically-concentrated industries is the biggest stimulus for growth. It is posited that the presence of multiple rivaling individuals might be the source of important incentives for out-performing the competitor. Considering the economics of superstars in which 'small numbers of people earn enormous amounts of money and dominate the activities in which they engage' (Rosen, 1981) and a 'Winner-TakeAll Society' (Frank and Cook, 1995), the importance to write better works than fellow composers seems to be of considerable importance also in classical music. The high

\footnotetext{
${ }^{3}$ See also Kelly and O'Hagan (2007) for an extended discussion of the factors why creative people might benefit from geographic clustering.
} 
concentration of composers might create a very competitive working environment, where only extraordinary performance is acknowledged. Amadeus Mozart (1756-1791) was aware of that and was mostly motivated to make his presence in the French capital:

In Paris they are accustomed to hear nothing but Gluck's choruses. Only place confidence in me; I shall strive with all my might to do honor to the name of Mozart. I have no fears at all on the subject. (Letter of 28 February 1778)

In 1778, the year Mozart spent in Paris, his productivity peaked and he wrote 19 influential compositions, as recorded in Gilder and Port (1978). Furthermore, his productivity was in that year three times higher than his annual average of around 6.6 compositions.

The third theory of positive externalities associated with geographic clusters is proposed by Jacobs (1969), who argues that the most important knowledge transfers come from outside the core industry. The dissemination of complementary knowledge between economic agents of diverse backgrounds facilitates innovation. In a geographic cluster thus the presence of a high degree of diversity might lead to increasing returns. Knowledge may spillover between composers specializing in different types of works (e.g. concert or theater works) or between composers and other creative individuals (e.g. writers). In fact, composers of the time period analyzed were highly literate and fully part of the cultured world of the local elite. The diverse entourage of composers is well documented in a letter from Berlioz to his sister Adele:

Last Monday we had a kind of little country outing. My friends came to spend half a day with us. They included famous musicians and poets, Messrs. Alfred de Vigny, Antoni Deschamps, Liszt, Hiller and Chopin. We talked and discussed art, poetry, thought, music, drama, in short everything that constitutes life (...). (Letter of 12 May 1834)

Franz Schubert's (1797-1828) tremendous productivity was mostly due to his unique ability to fuse poetry and music. Schubert continually sought out verse that conveyed meaning and was suited through its declamation for musical realization. His assiduous search led him to more than 150 poets, including Goethe, Klopstock, Ruckert and Schiller. The literary works of Heinrich Heine (1797-1856), who spent the longest part of his career in Paris, were set to music by a number of composers such as Robert Schumann, Johannes Brahms (1833-1897), 
Hugo Wolf (1860-1903), Pietro Mascagni (1863-1945) and Felix Mendelsohn.

Further location benefits could stem from economies of scale as a result of sharing the same specific cultural infrastructure, for example, a concert hall and symphony orchestra or an opera house and opera company, i.e. infrastructure that is very cost intensive and necessitates a critical mass both in form of demand and supply. Clustering benefits might be also attributable to the use of the same distribution channels. A letter from Liszt to Chopin documents a recommendation of a Parisian editor: “(...) you will have every reason to be satisfied with his [the editors'] activity and with whatever he does. Mendelssohn, whom he met in Switzerland two years ago, has made him his exclusive editor for France, and I, for my part, am just going to do the same" (Letter of 21 May 1845). On a different occasion, Liszt had recommended the works of Schumann to Pacini, a music Publisher in Paris, "This second arrangement is by Schumann, a young composer of very great merit. It is more within the reach of the general public, and also more exact than my paraphrase" (Letter of 30 September 1838). Furthermore, additional location benefits might stem from backwards linkages that are emerging in geographic clusters: the presence of composers led to better production of musical instruments, the development of music journals and reviews, the improvement of sheet music publication, and the higher attractiveness of acting as impresarios.

\section{Data}

The sampling technique aims at assuring maximum objectivity and reliability. As a result of data availability issues I focus only on prominent individuals and use the list of the most important composers from Murray (2003). Murray's work is based on numerous international references hence the risk of country- or marketing-biases in the selection is minimal. The study of human accomplishment is conducted for several fields, including classical music, and for each outstanding individual in every discipline an index score is determined, based on the amount of space allocated to her or him in the reference works. The index score is normalised for all individuals listed in each discipline so that the lowest score is one and the highest is 100 .

Data on composers' artistic output is taken from 'The Dictionary of Composers and Their Music' (Gilder and Port, 1978). The two prominent musicologists provide a list of 275 composers born between 1500 and 1949 with their important works dated and arranged chronologically. Gilder and Port aim to provide a dictionary 'of lasting value as a permanent 
reference (...) [that contains] (...) complete factual information about who wrote what, and when' (Gilder and Port, 1978, preface). The dictionary is a recognized survey of the most influential classical compositions and served often as a source for composer's output (e.g. Simonton, 1991). In a study like this it is important for a number of reasons to consider only the important works. First, the influential compositions are the reason why a composer is considered nowadays to be a prominent artist. Only such works made a significant contribution to the classical music canon and reflect composers' quality. Second, I eliminate the bias that would be caused by consideration of composers' jottings, trifling pieces or tentative works (i.e. by exercises of no lasting value), as well as propaganda pieces and some commercial productions (i.e. low-quality works written with a short-term profit orientation). A third implicit advantage is the omission of unfinished works. ${ }^{4}$ Combining both sources (i.e. Gilder and Port, 1978, and Murray, 2003) for the period analyzed an intersection of 116 composers emerges. 5

For those composers I extract background information from Grove Music Online (2009), the leading online source for music research. This large multivolume dictionary is detailed enough to track the movements of all 116 composers, especially work-related migration. It is 'a critically organized repository of historically significant information' (Grove, 2009, Preface) and hence is an ideal source for the purposes of this article. In this study I focus only on the periods of a composer's life when music-related work was predominant, i.e. when a composer was composing, giving tours, conducting philharmonics, teaching at music schools, managing music institutions, or travelling in search of inspiration. I therefore exclude from the analysis the infancy, time spent on education or training, retirement years, and periods when only other (i.e. not music-related) professions were exercised. The migration patterns of a composer are recorded from the first year he becomes involved in a music-related activity other than learning, which would be usually the composition of the first work. This is in order to avoid any potential endogeneity of the

\footnotetext{
${ }^{4}$ In the Robustness Section I employ Murray's Index Score as an alternative measure for composers' quality. The results remain consistent. I have also considered a number of other data sources on productivity, for example, performances at leading concert halls or CD releases. The alternative approaches are however hardly feasible, mostly due to lack of access to such data. Furthermore, one would not be able to disentangle the importance of a historical composer from the influence of a contemporary performer. Finally, concert repertoires and especially albums contain various works, sometimes even works written by different composers; separating the importance of a single piece would not be possible.

${ }^{5}$ Note that from now on with each reference to composer, I mean, prominent composer, the focus of this study. As the study encompasses only male composers, I use the male form.
} 
encompassed composers' decision to enter the labour market. ${ }^{6}$ A further source of bias might be the decision to exit the labour market and to retire. However, in the biographies of prominent composers, whose lives evolved around classical music, retirement is hardly observable. The only notable reason for retirement is an illness, which is sufficiently exogeneous. Furthermore, these restrictions are relaxed in a robustness test that is based on composer's entire lifetime (see Section 5.4).

Table 1 presents summary statistics on the sample encompassed in this study. It can be observed in Panel A that the average artist was engaged in music-related work during most of his life (around 45 out of 67 years). ${ }^{7}$ The duration of music related education or training lasted on average nine years. The father, mother or any other family member was often engaged in a music-related activity (e.g. father was composing, mother played violin). The average yearly output is equal to 0.77 and suggests that an artist composed roughly three important works every four years. The mean of Murray's Index Score (MIS) is equal to 12.7 points. Twelve per cent composers were born in the second half of the 18th century, one third were born in the first part of the 19th century and the remaining artists were born in the late 19th century (Panel B). Panel C shows the number of observations on the composer-year level. As around half of the studied composers have been born in the second half of the $19^{\text {th }}$ century, most observations are available for the $20^{\text {th }}$ century, when their careers were effectively taking place. The sample covers only deceased individuals (as the last composer died in 1989) and with around 5,000 observations it is sufficiently large for a reliable quantitative analysis. France and the Germanic countries (i.e. Germany, Austria or Switzerland) accounted for the highest share of births of composers - more than 20 per cent each, followed by Italy and Russia with each around 12 per cent of births (Panel D). The births of the remaining artists are fairly spread among other - mostly European - countries.

Next, I investigate what cities were the most important for the profession of classical composers. I conduct a ranking of major cities using four different criteria. First, I measure the total number of years all composers spent in each city encompassed by the data set. Second, I count composers who have visited a city at least once in their life. Third, I calculate how many times each location was chosen as the main work destination, i.e. where a composer spent the longest part of his musical career. Fourth, I total the number of composers' births for each city. The summary is presented in Table 2. It becomes obvious

\footnotetext{
${ }^{6}$ While taking on the first occupation in the music profession might be endogeneous to locating in a geographic cluster or to composer's quality, there are hardly any reasons, why composition of the first work would be.

${ }^{7}$ See Table A1 for an extended list and essential background information of composers included in this study (not for publication).
} 
that Paris was the predominant location, where composers have spent a total of 1,589 years. The French capital was visited by 66 composers and was the birthplace of nine. While Paris emerges as the most important geographic cluster, also other locations played a role. ${ }^{8}$ London was visited by 39 composers and chosen as primary destination by nine artists, while Vienna was visited by 35 composers and served for 13 artists as the main work location. The importance of the fourth most important city - St. Petersburg - is considerably lower and each further city played a smaller role. ${ }^{9}$

The above observations can be reaffirmed when comparing the importance of cities throughout the entire time period. Figure 1 illustrates the number of composers located in Paris, Vienna, London, as well as in ten other cities that follow in importance the three exclusively-analyzed locations. Paris was consistently the single most important location throughout the entire time-period. The significance of Vienna and London can also be confirmed.

Table 3 presents a brief summary for each of the three predominant locations (i.e. geographic clusters). Information on all composers is compiled in Panel A and on composers born in any of the geographic clusters is summarized in Panel B. In accordance with O'Hagan and Borowiecki (2010) composers born in Paris remained remarkably immobile. For example, out of the nine artists born in the French capital, three never left the city and the remaining spend less than two years outside their city of birth. The time spent outside the Viennese and London clusters is approximately 8 years and hence considerably higher.

\section{Identification}

The aim of the econometric analysis is to estimate the causal relationship between composers' productivity and the incidence of geographic clustering. For this reason the following two-stage least-squares model is utilized:

\footnotetext{
${ }^{8}$ The dominance of Paris was also argued by Hall (1998), albeit without quantitative support. Hall identified the French metropolis as 'the capital of light' for cultural activity that attracted not only artists but also intellectuals throughout the world.

${ }^{9}$ St. Petersburg is not included in the main specifications as it is an outlier with regard to its location. The average birthplace-cluster distance equals 1,339.8 miles (St. Dev. 1,905.5), which is almost twice as high as for Paris, more than twice the distance to London and around 3.5 times higher than for Vienna. This remoteness is also reflected in the number of composer visits to St. Petersburg. Only 20 composers have travelled to the Russian cluster, whereas Vienna was visited by 35, London by 39 and Paris by 65 . These are fundamental differences that strongly impacted who and for how long have visited St. Petersburg. As a result any comparison with other cities might become difficult. Using geographic distance between composer's birthplace and St. Petersburg in order to instrument for the incidence of locating in St. Petersburg, does not deliver any significant location benefits (not reported).
} 


$$
\begin{aligned}
& \text { Output }_{i t}=\alpha_{0}+\alpha_{t}+\beta \text { Cluster }_{i j t}+\gamma_{1} \text { Age }_{i t}+\gamma_{2} \text { Age }_{i t}{ }^{2}+\varepsilon_{i t} \\
& \text { Cluster }_{i j t}=a_{0}+a_{t}+b \text { Distance }_{i j}+g_{1} \text { Age }_{i t}+g_{2} \text { Age }_{i t}{ }^{2}+\mathrm{e}_{i t}
\end{aligned}
$$

Annual productivity of composer $i$ in year t $\left(\right.$ Output $\left._{i t}\right)$ is regressed on a dummy variable $\left(\right.$ Cluster $\left._{i t}\right)$ that is equal to 1 if composer $i$ lived in a geographic cluster $j$ in year $t$. Employing ordinary least squares (OLS) to estimate Equation (1a) cannot identify the causal effect of locating in a geographic cluster if there is some component of the error $\varepsilon_{i t}$ (e.g. unobserved skill) that is correlated with location choice. In order to deal with potential endogeneity of the incidence of clustering, I identify the location variable using Equation (1b). The geographic distance between the birthplace of composer $i$ and the geographic cluster $j$ (Distance $i j$ ) is employed to instrument in the first stage for the incidence of clustering.

Several remarks are in order. The birthplace-cluster distance is captured as a logarithm in order to allow for decreasing importance of large distances. ${ }^{10}$ It would be most desirable to use a measure of economic distance that accounts for travel times, travel cost and cultural differences. One possibility would be to approximate economic distance with trade flows. Inter-city trade data is however mostly unavailable or incomplete. I propose therefore, to use linear distance ('air-line distance'). ${ }^{11}$ In order to account for unobserved changes over individual's lifetime, I include a quadratic age polynomial $\left(A g e_{i t}\right.$ and $\left.A g e_{i t}{ }^{2}\right)$. The quadratic term takes also account of decreasing productivity levels at higher ages. The estimated equations contain further a set of time dummies $\left(\alpha_{t}\right)$ to deal with intertemporal differences in travel possibilities or productivity levels. The introduced indicator functions for time take the value one for each decade and zero otherwise. Finally, the model contains a constant $\left(\alpha_{0}\right)$ and a standard variance estimator $\left(\varepsilon_{i t}\right){ }^{12}$

The validity of the identification strategy rests on three assumptions. First, there exists

\footnotetext{
${ }^{10}$ For composers born in a geographic cluster (i.e. when the birthplace-cluster distance is equal to zero) the Distance $_{i j}$ term is likewise set equal to zero. An alternative way to account for decreasing importance of large distances is to use a quadratic distance polynomial. This however might lead to over-identification. With the aim to keep this research as simple and robust as possible, primarily a single logarithm distance term is employed. Nonetheless, the results would remain consistent throughout all specifications if different measures of the birthplace-cluster distance were employed (e.g. distance measured at level or as a quadratic polynomial; not reported).

${ }^{11}$ A similar solution is proposed by Dittmar (2012) who employs linear distance from Mainz, where the printing press was invented, as an instrument for the incidence of printing technology adoption in European cities. As air-line distance is only an approximation of the unobserved economic or cultural distance, the correlation between the instrument and the endogeneous variable will contain some bias.

${ }^{12}$ In some robustness estimations, the standard errors are clustered, for example, at the city (or composer) level, allowing for correlations between observations within a single city (or composer), but remaining independent between cities (or composers). The results remain consistent with a marginal decrease in significance (not reported).
} 
a significant first-stage relationship with sufficient explanatory power. I investigate therefore the probability to locate in a geographic cluster as a function of the logged birthplace-cluster distance. The estimated probabilities to locate in Paris are presented in Panel A of Table 4. Using OLS, the first-stage relationship between birthplace-Paris distance and the probability of locating in Paris in a given year is determined precisely at statistical confidence levels of over 99 percent. Column (1) presents the correlation coefficient for a model without any control variables while column (2) reports the results for a model with the previously introduced control variables, that is an age polynomial and decade controls. The coefficient on the birthplace-cluster distance variable is estimated with high precision and remains consistent in both specifications. The $R$-squared coefficient implies that around 28 per cent of the variation in the dependent variable is explained by the distance term and the explanatory power increases only marginally if the additional set of age and time controls is included, indicating the predominance of geographic distance in explaining a location choice. I further extend the analysis by including two further cities that were very important destinations for classical composers: Vienna and London. I report in Panel B of Table 4 the corresponding probability-to-locate-coefficients for all three predominant locations. The point estimates for all three cities are in general comparable in size, sign and significance to the estimations for Paris on a stand-alone basis. ${ }^{13}$ There is also no sign of the instrument being weak (CraggDonald eigenvalue statistics are at least 55.3). ${ }^{14}$ Composers born further away from the cluster are typically less probable to locate in it. As hypothesized, geographic distance is found to be a significant factor in determining a person's location choice. The negative relationship for Paris as well as for all three geographic clusters is presented graphically in Figure 2, using a local polynomial regression method with an Epanechnikov kernel. It can be viewed that the relationship would remain stable also if composers born in a cluster (i.e. individuals whose birthplace-cluster distance is equal to zero) are excluded.

The second required condition for the validity of the instrumental variable employed is that the exclusion restriction holds. The instrument cannot be correlated with the error term in the Model (1a), that is $\operatorname{Cov}\left(\varepsilon_{i t}\right.$, Distance $\left._{i j}\right)=0$. Put another way, composers' output must depend on geographic clustering, and the birthplace-cluster distance impacts

\footnotetext{
13 The coefficient on the distance between composers' birthplace and Vienna is somewhat smaller in size compared to the other estimates. This is presumably caused by the central location of Vienna in Europe.

${ }^{14}$ Stock and Yogo (2005) propose a test based on the Cragg-Donald minimum eigenvalue statistic to investigate for weak instruments. Stock and Yogo estimate the critical value of the Cragg-Donald eigenvalue statistic to be equal to 16.38 for a model with one endogenous regressors and one instrument, and 22.30 for a model with one endogenous regressors and three instruments. The reported Cragg-Donald eigenvalue statistics at the bottom of each Panel of Table 3 clearly exceed the critical values and hence indicate little risk of weak instrument bias.
} 
composers' productivity only through its impact on clustering. Now, it might be the case that composers who locate not directly in a cluster but in its vicinity, might benefit from the proximity to a cluster, for example, because of better access to existing ideas. To prevent this kind of proximity-effect I treat all locations within a radius of 50-miles from Paris, Vienna or London as the geographic cluster itself. ${ }^{15}$

The exclusion restriction could be further violated by unobserved learning or dynamic location choice issues. Particularly as a time-invariant instrument (geographic birthplacecluster distance) is used in order to model a time-varying variable (the incidence of locating in a geographic cluster in a given year). Suppose that unobserved skill is some nonlinear function of lifetime location decisions and that high-ability composers acquire skills more quickly over time, which might be particularly likely to occur in clusters. In this case, the instrumental variable ( Distance $_{i j}$ ) is related to productivity $\left(\right.$ Output $\left._{i t}\right)$ through a channel other than locating in a geographic cluster $\left(\right.$ Cluster $\left._{i t}\right)$ - namely, past location decisions Cluster $_{i, t-1}$, Cluster $_{i, t-2}$, etc. Another way to put it is this. If we really think that composers learn over time and the speed of learning varies by ability and cluster location, then maybe we would want to include the entire location history vector (i.e. Cluster $_{i t} \equiv\left[\right.$ Cluster $_{i, t-1}$, Cluster $\left._{i, t-2}, \ldots\right]$ ) in the second-stage regression (Equation 1a). But then, we would have many endogenous variables (one location for each age) and only one instrument (distance between birthplace and each location). As a result the system would be under-identified. Intuitively, we have an instrument that is plausibly valid for initial location choice, but the decision to remain in Paris is probably related to unobserved innate ability or unobserved learning over time. This concern would be inexistent if composer's probability of locating in a certain location in a given year depended equally throughout his entire lifetime on the birthplace-cluster distance. In such situation year-by-year variation of the distance term would be not necessary in order to calculate a reliable correlation coefficient between the variables of interest. The underlying sample covers individuals who, if they have once chosen to visit any of the centers for classical music, they most likely spent consecutively a significant part of their career there. In particular, composers whose main work location was Paris, spent 87 per cent of their career in Paris, for Vienna this share is equal to 67 per cent and for London 83 per cent (Table 3). This implies a potentially very persistent role of geographic distance on the location choice.

${ }^{15}$ The size of the radius was used by O'Hagan and Borowiecki (2010). In only three cases the locations had to be readjusted. Claude Debussy was born in St Germain-en-Laye and Georges Bizet spent some time during 1870's in Bougival. Both locations lie approximately 10 miles from the city center of Paris and are treated as Paris. Sir Arnold Bax was born in Streatham, less than 10 miles from the city center of London. At present, the three locations discussed are districts of Paris or London. 
By including a quadratic age polynomial I further control for eventual differences arising due to composers' age effects. The identification strategy provides thus reliable average point estimates for the effect of birthplace-cluster distance on the incidence of locating in a cluster location, all else remaining equal. Furthermore, in Section 5.2 I conduct a test of the above discussed concern and use time-varying instrumental variables that allow to model dynamic location choice. The results are found to be robust.

Third, the instrument needs to be as good as randomly assigned. Given that a person cannot affect his birth location after he is born and that births are almost uniformly dispersed over geographic space this assumption seems to be satisfied. Furthermore, there is relatively little parental choice over location of birth, especially in a period when migration was difficult. A potential violation might however result if families that, for example, place a strong emphasis on musical education chose to live in or close to a geographic cluster. Children of these families may have better musical skills or better access to a relevant social network. Either factor could induce a positive correlation between the incidence of clustering and the unobserved determinants of productivity (i.e. $\varepsilon_{i t}$ in Equation 1a), leading thus to violation of the randomness assumption. I therefore employ data on musical background of composer's family members (as recorded in Grove, 2009) and investigate this concern below.

I begin by estimating the effect of engagement of any family member in a musicrelated activity on composers' probability to locate in one of the three geographic clusters. The results are reported in columns (1) to (4) of Table A2. It can be viewed in column (1) that the estimated coefficients are marginal, usually not significant and have almost no explanatory power. In column (2) I demonstrate that the controls introduced for the musical background of composers' family members do not bias the distance terms. Next, I split all composers into two samples depending on whether a family member was involved in music. I report in column (3) the impact of the birthplace-cluster distance on clustering for composers who had at least one family member engaged in any music related activity. In column (4) I present the results for composers with no such family member. The distance effect is very similar for both sub-samples. I further analyze the relationship between the indicators for music background of composers' family members and the birthplace-cluster distance itself. The results are presented in column (5) of Table A2. This is the most demanding test as it analyzes to some extent the spatial distribution of composers' birth locations and not only the incidence to locate in the geographic cluster. The estimated coefficients are in general insignificant and have marginal explanatory power. It is reassuring that the family controls included or sub-sampling do not affect the probability to locate in any geographic clusters nor 
it is related with the birthplace-cluster distance. It can be concluded that composers' decision to locate in Paris, Vienna or London, as well as their birth location was fairly independent from the influence of family and hence the risk of non-randomness of the instrument mitigates.

With further confidence in the validity of the proposed instrumental variables a brief demonstration of the unique importance of distance in historical time periods is provided. I argue that geographic distance was a decisive factor for the choice of a work location in historical time periods when travelling was constrained, by time or cost. I therefore divide all annual observations equally into four different time-periods and investigate how the importance of the distance variable changes over time. The results are summarized in Table A3. To facilitate interpretation of the distance coefficients the term is presented at level. The estimated coefficients are the largest in size and most precisely estimated for the earlier decades, until roughly the 19th century. If a composer was born 1000 miles further away from Paris, he was more than 50 per cent less likely to migrate towards the French capital. From the beginning of the 20th century the relevance of distance diminishes markedly: the coefficients fall in size and the explanatory power of the restricted model drops (the $R$ squared term decreases from close to 0.3 to around 0.05 ). In the last sub-period a birthlocation 1000 miles further away from Paris, coincides with a decrease in the probability to cluster in the French metropolis only by around 4.2 per cent. Employing average distances from Paris, Vienna or London I estimate the probability to locate in any of the three geographic clusters and find consistent results. Those patterns provide indication that the proposed identification strategy works best, if not only, for historical periods and supports the view that travelling in such periods was indeed difficult and costly.

\section{The Effect of Geographic Clustering on Composers' Productivity}

\subsection{Main Results}

In the following, I analyze the effect of locating in a geographic cluster on composers' productivity employing the previously proposed model. Table 5 summarizes the results using OLS estimation, composer fixed-effects (FE) model and instrumental variable (IV) specification for Paris (Panel A) and for Paris, Vienna or London (Panel B).

Columns (1) and (4) show the OLS relationship between locating in a geographic cluster and the number of written compositions in a given year. The correlation between clustering in Paris and composers' output is negative without or with inclusion of the control 
variables. ${ }^{16}$ This implies that composers located in the predominant hub for classical music have not been more productive than the average composer. The negative association disappears in the FE model (columns (2) and (5)). This might imply that the previously observed lower productivity in Paris is a result of unobserved differences between composers. The IV estimates are presented in columns (3) and (6). The IV results yield a positive coefficient in both specifications, however only in the model with control variables the coefficient is significant (and exposes a $p$-value of below 0.01). ${ }^{17}$ Since I have instrumented for the incidence of clustering, the causal assertion can be made that composers benefited from the positive externalities associated with the geographic cluster. In the preferred specifications (after I control for age effects and time trends) the estimated IV parameter is equal to around 0.24: a composer who worked in Paris was creating around one additional work every four years as a result of being located in the cluster. If one considers the average annual productivity of composers (i.e. 0.77 works per year, Table 1), the size of the estimated impact of clustering on productivity is economically relevant and indicates that almost one third of composers' output was a result of the positive externalities associated with a cluster. Paris - the predominant location for classical music - has attracted less productive composers who, on average, experienced large productivity gains.

The results for the aggregated analysis of the three cluster locations are presented in Panel B of Table 5. It can be observed that the OLS coefficients are positive and very significant. The positive association diminishes in size and significance once composer fixedeffects are introduced. The IV specification delivers once again positive, significant and large coefficients. This means that composers benefited significantly in terms of productivity due to locating in any of the three main geographic clusters. One additional work has been composed every three years spent in either of these locations, which implies a large productivity increase of close to 50 per cent.

In all specifications the estimated IV parameters are always considerably higher than the corresponding OLS or FE point estimates. There could be a number of reasons for this difference. First, it is possible that locating in geographic clusters not only stimulates productivity but also attracted individuals who were less productive than the average artist. In this context, negative self-selection of composers to the most important locations for classical

\footnotetext{
${ }^{16}$ As described in the previous section, the control variables include a composer-specific time trend, estimated with a quadratic polynomial (i.e. age and age-squared), and time controls, estimated with an indicator function that is equal to one for each decade (and zero otherwise).

${ }^{17}$ The point estimate on the clustering impact in the restricted model (column (3)) has a $p$-value equal to 0.14 and lies thus not far outside of the usual confidence intervals.
} 
music might somewhat equalize the clustering benefit and hence attenuate the OLS estimates. Second, there might exist a proxy measurement error leading to a bias of the OLS coefficients. Changes in composers productivity was not the result of their physical presence in the geographic cluster but perhaps rather their interaction with other creative individuals. A binary indicator that records whether or not a composer was located in a geographic cluster is only a rough approximation for social interactions. In consequence, measurement error might attenuate the OLS coefficients, while the IV identification possibly picks up a more robust measure of the effect of geographic clustering. The attenuation bias is visible however only in Panel B of Table 5.

Another reason why higher IV parameters have been obtained might be the fact that these parameters can be interpreted as a Local Average Treatment Effect as proposed by Imbens and Angrist (1994). It is possible that certain types of composers benefit to a different extent from clustering. This could be the case if, for example, the best composers who cluster are able to benefit more from the location due to some unobserved characteristics. As a result the clustering effect for those composers might be greater. I investigate this possibility by dividing composers into top 10 composers (ranked by Murray's Index Score), all remaining composers and the bottom 16 composers. ${ }^{18}$ The IV results are reported in columns (2) to (4) in Table 6 (column (1) reports the baseline results). The obtained differences in the IV point estimates are remarkable. Column (2) presents the IV results for the highest ranked composers and implies that clustering returns to composers' productivity are considerably higher for the top 10 composers than for the full sample. ${ }^{19}$ Column (3) presents IV estimates for all remaining composers (i.e. after the top 10 composers are excluded). It can be concluded that the coefficients slightly decrease, remain however significant and consistent with the baseline findings. Column (4) shows the clustering effect on the output of the worst 16 composers. Interestingly, the IV coefficient is now negative and insignificant for composers locating in Paris. For the three clusters it decreased considerably in size and is estimated with lower precision.

One further source of heterogeneous responses to geographic clustering might depend on whether the individual was born in the cluster or moved to it during his life. It is again quite likely that composers who moved to the geographic cluster have experienced very

18 The worst composers are individuals with a Murray's Index Score of two or below. It is the lowest possible cut-off point, as none of the three composers with a Murray's Index Score of one has visited any of the cluster locations.

${ }^{19}$ This finding is consistent with previous research. For example, Waldinger (2010) studies peer effects among university scientists and finds greatest clustering externalities for students in top 10 departments. 
different location benefits at the new destination than the local artist. This could be attributable to, for example, the diverse background and experience of the migrant composer. I analyze this possibility by excluding from the full sample composers who were born in one of the geographic clusters analyzed..$^{20}$ In column (5) of Table 6, I first drop ten composers who were born in Paris and re-estimate the parameters based on 106 artists who, if located in Paris, then only due to migration from other places. Next, I exclude 18 composers who were born in Paris, Vienna or London and establish for the remaining individuals the effect of locating in any of the three clusters on their productivity. The IV estimates for the migrant composers located in Paris yield markedly higher coefficients of around 0.44, while remaining highly significant. The estimated parameters for the migrant composers almost double in size and indicate that migrant composers experienced a distinctly higher benefit due to the positive externalities associated with locating in Paris. No such difference can be observed if Vienna and London are further introduced into the analysis. This could be attributed to the previously described remarkable immobility of the Parisian composers. Out of the 10 artists born in Paris, three never left the city and the remaining spend on average less than two years outside the French metropolis. I conclude, in geographic clusters top composers were greater beneficiaries than the average artist. Furthermore, some amount of travel or exposure to different work environments seem to have been of benefit to composers' productivity.

\subsection{Robustness Analysis}

In the following, I report a large number of tests that indicate that the findings are very robust. The results are presented in Table 7. First, I include an additional indicator function controlling whether any parent of the composer was engaged in a music related activity. Given that the source of the data set - the Grove Music Dictionary - records music-related engagements of the parents only if they are of considerable quality and importance, the variable should serve as a good proxy of composers' musical skills. The results are presented in column (2) of Table 7 (column (1) reports the baseline results). The estimated coefficients are now marginally smaller, but remain very precise. ${ }^{21}$ This indicates that the presence of parental music-related background has been of some benefit to composers' productivity. The main results find nevertheless support for their reliability.

\footnotetext{
${ }^{20}$ Note that all of the excluded composers have also spent the longest part of their work lives in the geographic cluster (i.e. in their birth locations).

${ }^{21}$ The estimated coefficients on parental music-background is equal to 0.15 ( $p$-value below 0.01 ) for Paris and 0.14 ( $p$-value below 0.01) for all three clusters.
} 
During composers' music related education, whether it was private tuition or formal studies in conservatoires, relevant personal ties were likely to have been established. It is therefore possible that individuals' clustering benefit varied depending on the music-related education time. I hence introduce further controls for the duration of musical education as recorded in Grove (2009). The point estimates, reported in column (3), provide further support for the robustness of the main findings. ${ }^{22}$ It is encouraging that the results remain consistent even if these powerful individual controls (parental music background and duration of music education) are introduced.

It is possible that geographic distance between a composer's birthplace and a cluster location approximates not only the travel cost, but reflects also to some extent institutional arrangements of the country of origin. If this was the case, the distance might impact composers' productivity not only through the incidence of clustering but also through some other channel such as, for example, better music education. In order to investigate such possibility a comprehensive set of 21 indicator functions for each of the recorded nationalities is included. The estimation is presented in column (4). The point estimates are found to be consistent in sign and satisfactory in significance with the baseline specification. The coefficients however fluctuate somewhat in size. This could be attributable either to unobserved international differences or to the decreased performance of the instrumental variable (after including controls for nationality, the birthplace-cluster distance loses some of its precision). These results might hence point at the presence of some degree of heterogeneity between nationalities. It is however important to note that the point estimates on the clustering effect passes this test and provides further support for the existence of benefits associated with geographic clustering. ${ }^{23}$

One may worry that some of the composers' visits to a geographic cluster were so brief that exchange with other artists was not possible due to time constraints. In such cases, the estimated coefficients might be biased. I therefore re-estimate the regressions omitting the observations in which composers remained in the cluster less than one year. ${ }^{24}$ The results which are reported in column (5) hardly change.

A related concern is that while only 18 composers were born in any of the three geographic clusters, markedly more died in Paris (30 composer deaths), Vienna (8) or

\footnotetext{
${ }^{22}$ The estimated coefficients on music related education time is equal to 0.02 ( $p$-value below 0.01 ) for Paris and 0.02 ( $p$-value below 0.01 ) for all three clusters.

${ }^{23}$ The results are robust to several other related tests that have been conducted (e.g. sub-sampling by the nationality; not reported).

${ }^{24}$ Note that while Grove (2009) includes very detailed information on composer travels, the data is very often available only on annual basis.
} 
London (7), and the death year of each individual was not a full year of creative work, unless the death occurred on the last day of December which is very unlikely. I analyze this issue by estimating the regressions after the death year has been excluded from the analysis. The coefficients reported in column (6) are estimated with high precision and remain positive. Encouragingly, the results can be reaffirmed.

Another worry is that composers might have visited not only the geographic cluster but also a different location in a given year. This could bias the clustering effect due to the externalities associated with the other location. I investigate this concern by re-estimating the regressions after excluding observations for years in which a composer has visited more than one location. Again, the results, as reported in column (7), are very consistent.

It is possible that the incidence of war influences the productivity of a creative individual. Borowiecki (2011) demonstrates that historical wars had a heterogeneous impact on classical composers' creative production. Depending on the type of war, military conflict might have had a positive or a negative effect. As the analysis is conducted for a very long time period during which a number of wars occurred, I address this concern by re-estimating the regressions while focusing only on years with no major exogenous shocks, such as war or epidemics. ${ }^{25}$ The IV results, as presented in column (8), indicate that the results are not driven by any exogenous disruptions.

Given the statistical explanatory power of the endogeneous variables, it is quite unlikely that any meaningful bias arises from the fact that the instrumental variable is timeinvariant. Nevertheless, I investigate empirically this concern by employing instead a timevarying instrumental variable that would allow to model dynamic location choice. This is achieved in two ways. First, I interact the birthplace-cluster distance with composers' age. Even if such artificially created variable has little economic meaning, in a statistical sense, it is a variable that is both time-varying and exogeneous to composers' output, and hence is valid for the intended purpose. Second, I obtain an interaction term between birthplacecluster distance and the incidence of intra-state conflict. War is arguably a factor determining people's location choice. For example, Borowiecki (2012) posits that during intra-state wars the aggregate number of composers in a country decreases by around 11 per cent (a decrease is also associated with international continental wars, however the effect is of a lower

\footnotetext{
${ }^{25}$ I exclude the years in which any of the following conflicts or epidemics occurred: the French Revolution (1789-99), Napoleonic Wars (1799-1815), the cholera outbreak in 1832 and 1849, the war on Prussia (1870-71) and both World Wars (1914-18 and 1939-44). I find consistent results also after excluding only single observations for composers who were located in a given year in a country that was engaged in war or in a region affected by the epidemic outbreaks. I report the results only for the stronger test.
} 
magnitude). Using the Correlates of War database (Sarkees, 2000) I obtain an indicator function that identifies the countries that have been involved in a civil war in a particular year. Employing the war dummy in connection with the geographic birthplace-cluster distance provides thus an alternative time-varying identification strategy.

The results from the first-stage specification are reported in columns (1) and (3) of Table A4, using either of the time-varying instrumental variables. The point estimates of the interaction terms are highly significant and deliver a sufficiently high Cragg-Donald eigenvalue statistic. Columns (3) and (4) summarize the coefficients for the endogenized location variables. The results imply a positive and significant causal effect of locating in any of the studied geographic clusters on composers' productivity. The IV parameters are comparable in size with the coefficients from the main model. This constitutes meaningful support for the robustness of the identification strategy.

A further concern deals with the external validity of the selected sample. The analysis is conducted at composer-year level and I estimate the impact of locating in a city with a high geographic concentration of composers (i.e. in a geographic cluster) on their productivity levels. In the clusters analyzed, apart from prominent composers (for only which data is available) many other composers, whose life accomplishments were not great enough to be listed in music dictionaries, were located. It is also likely that composers encompassed in the analysis interacted with other not-listed artists. By establishing the impact of locating in a geographic cluster, I therefore also account for the benefit due to interactions with all other creative individuals located in the cluster location. In result, the proposed identification strategy mitigates some of the non-random extreme sample selection bias. ${ }^{26}$

\subsection{Large City and Historical Cluster Effects}

It is possible that composers benefited in geographic clusters not only due to the concentration of other artists (e.g. due to knowledge spillovers), but also due to some large city specific factors. In large cities one might expect higher demand for composers' works or services, better cultural infrastructure or easier access to related industries (e.g. sheet music publishers). All such large city amenities correlate strongly with composers' clustering intensity. It is therefore unlikely that any of the estimated cluster effects might not be related

\footnotetext{
${ }^{26}$ An alternative way of estimating clustering benefits would be to estimate the total number of composers in each location and to establish its impact on composers' productivity. The problem arising with such identification strategy is that the distribution of non-prominent composers is not clear. Consider, for example, unique work-location choices due to individual specific reasons (e.g. Frederic Chopin and George Sand stay in Majorca in 1838-39).
} 
(directly or indirectly) to composers' clustering intensity. Nonetheless, I address this issue by running two falsification tests.

First, I estimate how composers' productivity was impacted by the incidence of locating in large cities that were not clusters for classical music. For this exercise, I select all cities that had in 1750 a population size of at least 100 thousand (as recorded in Mitchell, 1975) and were not a common destination for classical composers. I identify eight non-cluster large cities: Amsterdam, Copenhagen, Hamburg, Madrid, Milan, Naples, Palermo and Venice. ${ }^{27}$ Analogous to the previous methodological approach, I instrument for the incidence of locating in any of those cities with distances between composers' birthplace and each city, in order to estimate the associated causal productivity gains. It is econometrically a very difficult task, as I focus on variables with very few non-zero observations and hence extremely little variation. I therefore aggregate all large non-cluster cities and store them under one variable (non-cluster large city).

Second, I investigate the impact of locating in cities that have been geographic clusters in the past, but lost its importance in the studied period. Such locations are most likely to own good cultural infrastructure and have superior institutional arrangements, however do not have any more a substantial share of classical composers. The focus of this test is directed at Italian cities which were the most important places for classical music, both in terms of birth locations and destinations, during the $15^{\text {th }}$ and $16^{\text {th }}$ centuries (see Borowiecki and O'Hagan, 2012). During the Renaissance, classical music achieved in Italy new heights of cultural respectability and contributed to a remarkable development of music production in the centuries to come across Europe. Music education has been institutionalised and was based in the newly founded music conservatories (e.g. Santa Maria di Loreto in Naples in 1537). Relevant supply industries, such as manufacturing of music instruments, have seen significant inventions. Those improvements contributed to the development of Italy's violins, violas and cellos which maintained most of its reputation and characteristics into modern days (e.g. produce by Stradivari, based in proximity of Milan). Technological developments occurred also in construction of buildings, which became greater in size and superior in resonance (e.g. Basilica of Saint Mark in Venice or the opera house La Scala in Milan). All those developments in musical education, music instrument production or relevant

${ }^{27}$ The average composer worked in any of those eight cities around 0.54 years (standard deviation 1.64) during his life. The large non-cluster locations were visited on average by 4.75 composers (standard deviation 3.5). Mitchell (1975) lists six further cities with population size above 100 thousand in 1750 (i.e. London, Moscow, Paris, Rome, St. Petersburg and Vienna). Those cities are however not included in the placebo test as they have been important locations for classical music. 
architecture contributed to the development of outstanding cultural infrastructure in Italy. It is also very likely that those amenities persisted over the following centuries, even if Italy ceased to be a major destination for classical composers. In fact, Italian music education, instruments produced in Italy or architecture of Italian opera houses and concert halls is viewed even nowadays to possess exceptional merit. For this reason I select all cities that are listed by Borowiecki and O'Hagan (2012) as important locations for classical music during the $15^{\text {th }}$ or $16^{\text {th }}$ centuries. Those cities include Bologna, Florence, Milan, Naples, Rome and Venice. ${ }^{28}$ Using geographic distances between composers' birthplace and the studied historical clusters I instrument for the incidence of locating in them.

Table 8 presents the estimations for both falsification tests. Columns (1) and (2) report the OLS and IV parameters for all eight large non-cluster cities, whereas columns (3) and (4) present the findings for six Italian historical clusters. The results are striking: in both specifications the IV parameters turn to be negative, large and highly significant. A decrease in composers' productivity occurred if they located in a large city that was not an important destination for the profession or in a city that has been a geographic cluster in the past. This evidence points at the unique productivity enhancing role of contemporaneous classical music clusters. Productivity benefits are experienced perhaps less due to higher demand or better cultural infrastructure but rather due to the presence of other composers, which presumably allows for knowledge spillovers, input sharing, labor market pooling and other similar benefits.

\subsection{Alternative Productivity Measure}

One might criticize the shortcomings of the output variable. The number of written important compositions does not account for composer's achievements due to other music-related engagements such as teaching or performing. This might be especially the case for composers located in geographic clusters, as in those locations other engagements might have been particularly attractive and good available, leading to higher opportunity costs of composing. In this section I investigate this possibility and employ a broader measure of composers' lifetime productivity.

Murray's Index Score (MIS) is the broadest available measure of composers' lifetime achievements. Murray (2003) conducted a vast survey of outstanding classical composers

\footnotetext{
${ }^{28}$ Out of all composers who are listed in the Grove Dictionary and were born in any of those six locations around 57 per cent were born before 1750 . Whereas, the average birth rate of Grove listed composers born before 1750 , is equal to around 26 per cent.
} 
employing a wide selection of international references and based on the amount of space allocated to each composer in the reference works he calculates the MIS. The index is normalized on a scale between 1 and 100 .

The MIS is a time-invariant measure of composers' lifetime accomplishments, hence the robustness test is conducted for composers' entire lifetime. As in previous parts, the focus is on establishing the relationship between geographic clustering and composers overall lifetime productivity, measured with the MIS. For this reason I propose two ways to capture geographic clustering. First, I measure the total music-related working time that a composer spent in a cluster location. Second, I use a binary indicator with the value one if a geographic cluster was composer's main work destination, i.e. if the composer has spent the longest part of his musical career in the cluster. In order to deal with varying longevities and to allow for a typical concave age-productivity profile a quadratic life duration polynomial is introduced. I further control for time trends by including indicator functions for each of the three halfcentury birth cohorts. ${ }^{29}$

Table 9 reports the OLS estimates (columns (1) and (3)) and the IV results (columns (2) and (4)). The correlation coefficients for Paris and London are negative, albeit often not significant. For Vienna I find positive and significant OLS estimates. The IV parameters are always positive and statistically significant. Furthermore, the regressions yield always markedly higher IV estimates than the corresponding OLS coefficients. An additional year the composer spent in Paris resulted in a 0.24 point increase of his MIS and the choice of the French capital as the primary work destination resulted in a marked increase of 9.52 points on Murray's scale. For Vienna I obtain the highest and most precise IV results, presumably because of the intense concentration of top composers in the Austrian capital (see O'Hagan and Borowiecki, 2010). Encouragingly, the main findings are confirmed. The employment of a very different measure for composers' lifetime accomplishments and a different methodological approach (lifetime analysis instead of annual) does not alter the conclusions from the previous analyses.

\section{Conclusion}

This study addresses an important methodological problem that lies at the core of empirical literature on the positive externalities associated with geographic clusters. I attempt to overcome potential heterogeneity bias and endogeneity of clustering issues by using a unique

${ }^{29}$ The estimated equation is given by: MIS $_{i}=\beta_{1}+\beta_{2}(\text { Geographic cluster })_{i}+\beta_{3}(\text { Life duration })_{i}+\beta_{4}($ Life duration $)_{i}^{2}+\sum_{j=1}^{3} \beta_{\mathrm{j}}(\text { Birth cohort })_{\mathrm{ij}}+\eta_{\mathrm{i}}$. 
data set for 116 important classical composers born between 1750 and 1899. The research design enables use of exogenous distances between each composer's birthplace and a geographic cluster as instrumental variables for the incidence of locating in a geographic cluster. I find that composers who worked in a cluster benefited significantly in terms of written compositions and have been creating around one additional work every three years. The location benefit is even greater for top composers, which is in accordance with previous research, whereas no such benefits can be consistently found for lower-ranked artists. Migrant composers have been more productive if they moved to Paris, where the resident artists hardly ever left the cluster. This implies that some degree of mobility might be also of benefit to productivity outcomes. Individuals with a different background and diverse experience who moved towards a geographic cluster were possibly able to benefit more from the positive externalities of geographic clustering. All these productivity benefits originate in locations where other classical composers are present, as opposed to, in large cities or in historical clusters with eventually more wealth and better cultural infrastructure, but no fellow composers. Finally, this study provides an analysis of composers' overall lifetime accomplishments and provides some indication that the positive agglomeration externalities disclosed might benefit over long periods.

The insights provided in this article are quite different from a recent influential article by Waldinger (2012), who investigated peer effects among university scientist during the $20^{\text {th }}$ century and did not find any evidence for this. The difference arising could be caused by the specific nature of the profession of classical composers, in particular, by the winner-take-all type of economy. Arguably scientists have been also competing for publications in academic journals, nonetheless classical composers were presumably exposed to far greater rivalry and have been challenged to outcompete the adversary, as only one composer could have his works performed in the concert hall or opera house. Thus the importance to write not good, but better works than the peer seems to be of considerable importance in classical music. Furthermore, intellectual exchange has been much easier between scientists (even in the $20^{\text {th }}$ century), when ideas or knowledge could be diffused by the means of correspondence or through field journals. In the case of classical composers such interaction was mostly not possible and personal exchange has been crucial: one needed, for example, to listen to the work of the other composer in order to be able to comment on or to learn from it.

This study does not come without limitations. The evidence gathered supports the existence of strong benefits associated with geographic clustering. It is however out of the scope of this research to relate the clustering effects to any particular factor. It remains 
therefore undisclosed whether the benefits are attributable and to what extent to determinants such as knowledge spillovers, input sharing, labor market pooling or demand linkages. ${ }^{30}$ Furthermore, given the limited nature of the data used, the results are only suggestive. Finally, it must be noted that any generalization from this analysis which is based on a quite peculiar sample of classical composers in a historical time period is rather difficult. It is nonetheless likely that similar benefits were experienced by other creative individuals in history and perhaps are even nowadays. Contemporary composers, artists or maybe even entrepreneurs might experience comparable productivity gains.

Despite the shortcomings, the insights provided in this article are of relevance not only to research in urban economics (spatial density effects) and labor economics (in particular human capital formation theory), but also to cultural economics, as it provides the first empirical evidence for an often posited hypothesis that artistic production causally improves in creative centers. Given the recent rise in the importance of creative industries, which, for example, are argued to be a determining factor of future growth in Europe (European Commission, 2012) or developing countries (UNCTAD, 2010), this contribution seems particularly relevant as it provides strong support to the idea of creating and fostering creative clusters. It should be further noted that this research is also of relevance to the economic history literature. In particular, it shows the importance of geographic settings in historical time periods: once a composer was born, the main work location and also the duration of stay in the future work location is hugely influenced by the geography of his birth. This is supposedly much less so nowadays, in a world where any type of migration is cheaper and more common.

If one believes in the generality of the results from this research, policy implication can be derived for authorities responsible for developing geographic clusters, such as special economic zones. Since the location benefits stem primarily from interactions with other clustering agents, authorities should foster platforms that enable or facilitate such interactions. Furthermore, if the main beneficiaries of locating in clusters are individuals (or firms) coming from outside the region, it may be possible to generate mutual gains by fostering cooperation between existing clusters. One example would be exchange programs that enable individuals to switch between clusters; or programs that facilitate firms to launch branches in other geographic clusters. These prescriptions are offered with the cautionary note that further research is urgently needed to shed light upon the optimal size and

\footnotetext{
${ }^{30}$ Refer to Rosenthal and Strange (2001) or Ellison et al. (2010) for investigations of the factors that are most meaningful in explaining agglomeration benefits.
} 
concentration rate of geographic clusters. 


\section{References}

Becker, Heinz and Gudrun Becker. 1989. Giacomo Meyerbeer, a Life in Letters. London: Helm.

Borowiecki, Karol J. 2011. 'War and Creativity: Solving the War-Art Puzzle for Classical Music Composition.' Trinity Economics Papers No. 0711.

Borowiecki, Karol J. 2012. 'Are composers different? Historical Evidence on ConflictInduced Migration (1816-1997).' European Review of Economic History, forthcoming.

Borowiecki, Karol J. and John O'Hagan. 2012. 'Historical Patterns Based on Automatically Extracted Data: the Case of Classical Composers.' Historical Social Research, forthcoming.

Ciccone, Antonio and Rober E. Hall. 1996. 'Productivity and the density of economic activity'. American Economic Review, 86(1): 54-70.

Clark, Gregory. 2007. 'Technological Advance.' In A Farewell to Alms: A Brief Economic History of the World, 133-44. Princeton: Princeton University Press.

Commander, Simon, Mari Kangasniemi and L. Alan Winters. 2004. 'The Brain Drain: Curse or Boon? A Survey of the Literature.' In Challenges to Globalization: Analyzing the Economics. Robert E. Baldwin and L. Alan Winters, 235-278. Chicago: University of Chicago Press.

Dittmar, Jeremiah. 2012. 'Information Technology and Economic Change: The Impact of the Printing Press.' Quarterly Journal of Economics, forthcoming.

Desrochers, Pierre and Frederic Sautet. 2004. 'Cluster-Based Economic Strategy, Facilitation Policy and the Market Process.' Review of Austrian Economics, 17(2): 233-45.

Ellison, Glenn, Edward L. Glaeser and William Kerr. 2010. 'What Causes Industry Agglomeration? Evidence from Coagglomeration Patterns.' American Economic Review, 100(3): 1195-1213.

European Commission. 2012. Creative Europe: Commission unveils plan to boost cultural and creative sectors. http://europa.eu/rapid/pressReleasesAction.do? reference=IP/11/1399 (accessed March 2012).

Frank, Robert H. and Philip J. Cook. 1995. The Winner-Take-All Society. New York: Martin Kessler Books at The Free Press.

Gilder, Eric, and June G. Port. 1978. The Dictionary of Composers and their Music. New York and London: Paddington Press Ltd.

Glaeser, Edward L., Hedi D. Kallal, Jose A. Scheinkman, Andrei Schleifer. 1992. 'Growth in Cities.' Journal of Political Economy, 100(6): 1126-52. 
Glaeser, Edward L. and David C. Mare. 2001. 'Cities and Skills.' Journal of Labor Economics, 19(2): 316-342.

Grove Music Online, Oxford Music Online. 2009. Oxford University Press. http://www.oxfordmusiconline.com (accessed March-November 2009).

Hall, Peter. 1998. Cities in Civilization. London: Phoenix.

Hellmanzik, Christiane. 2010. 'Location matters: Estimating cluster premiums for prominent modern artists.' European Economic Review, 54(2): 199-222.

Hunter, Rosalind S., Andrew J. Oswald and Bruce G. Charlton. 2009. 'The Elite Brain Drain.’ Economic Journal, 119(538): 231-51.

Imbens, Guido and Joshua Angrist. 1994. 'Identification and Estimation of Local Average Treatment Effects.' Econometrica, 62(2): 467-75.

Jacobs, Jane. 1969. The Economy of Cities. New York: Vintage Books.

Kelly, Elish and John O'Hagan. 2007. 'Geographic clustering of economic activity: The case of prominent western visual artists.' Journal of Cultural Economics, 31: 109-28.

Krugman, Paul. 2009. 'The Increasing Returns Revolution in Trade and Geography.' American Economic Review, 99(3): 561-71.

Liszt, Franz. 2009, Letters of Franz Liszt. From Paris to Rome: Years of Travel as a Virtuoso. Charleston, SC: BiblioBazaar.

Mozart, Wolfgang A. 2004. The Letters of Wolfgang Amadeus Mozart - Volume 1. Whitefish, MT: Kessinger.

Murray, Charles. 2003. Human Accomplishment - The Pursuit of Excellence in the Arts and Sciences, 800 B.C. to 1950. New York: Harper Collins.

Nickell, Stephen J. 1996. 'Competition and Corporate Performance.' Journal of Political Economy, 104(4): 724-46.

O'Hagan, John and Karol J. Borowiecki. 2010. 'Birth Location, Migration and Clustering of Important Composers: Historical Patterns.' Historical Methods, 43(2): 81-90.

O'Hagan, John and Christiane Hellmanzik. 2008. 'Clustering and Migration of Important Visual Artists: Broad Historical Evidence.' Historical Methods, 41(3): 121-36.

Porter, Michael E. 1990. Competitive Advantage of Nations. New York: Free Press, 1990.

Robert, Frédéric. 1975. Hector Berlioz, Correspondance Générale II: June 1832-September 1842. Paris: Flammarion.

Rosen, Sherwin. 1981. 'The Economics of Superstars.' American Economic Review, 71(5): 845-58. 
Rosenthal, Stuart S. and William Strange. 2001. 'The Determinants of Agglomeration.' Journal of Urban Economics, 50(2): 191-229.

Rosenthal, Stuart S. and William Strange. 2004. 'Evidence on the nature and sources of agglomeration economies'. In Handbook of Regional and Urban Economics. Vernon Henderson and Jacques François Thisse, 4: 2119-71. Amsterdam: North Holland.

Sarkees, Meredith R. 2000. 'The Correlates of War Data on War: An Update to 1997.' Conflict Management and Peace Science, 18(1):123-44.

Scherer, F.M. 2001. 'The Evolution of Free-Lance Music Composition, 1650-1900.' Journal of Cultural Economics, 25: 307-19.

Simonton, Dean K. 1991. 'Emergence and Realization of Genius: The Lives and Works of 120 Classical Composers.' Journal of Personality and Social Psychology, 61(5): 829-40.

Spencer, Stewart and Barry Millington. 1988. Selected Letters of Richard Wagner. New York: W.W. Norton.

Stock, James H. and Motoshiro Yogo. 2005. 'Testing for Weak Instruments in Linear IV Regression.' In Identification and Inference for Econometric Models: Essays in Honor of Thomas Rothenberg. Donald W.K. Andrews and James H. Stock, New York: Cambridge University Press.

UNCTAD, United Nations Conference on Trade and Development. 2010. Creative EconomyReport 2010. Creative Economy: A Feasible Development Option. Geneva: United Nations.

Waldinger, Fabian. 2010. 'Quality Matters. The Expulsion of Professors and the Consequences for Ph.D. Student Outcomes in Nazi Germany.' Journal of Political Economy, 118(4): 787-831.

Waldinger, Fabian. 2012. 'Peer Effects in Science - Evidence from the Dismissal of Scientists in Nazi Germany.' Review of Economic Studies, forthcoming.

Wagner, Richard. 2008. My Life - Volume 1. Charleston, SC: BiblioBazaar.

Wooldridge, Jeffrey M. 2002. Econometric Analysis of Cross Section and Panel Data. Cambridge, MA: MIT Press. 


\section{Tables}

Table 1 . Summary statistics: 116 composers.

\begin{tabular}{|c|c|c|}
\hline & Mean & Standard Deviation \\
\hline & \multicolumn{2}{|c|}{ A: Background information } \\
\hline Life span (in years) & 66.85 & 15.07 \\
\hline Duration of career (in years) & 44.94 & 14.31 \\
\hline Education or training time (in years) & 8.90 & 5.38 \\
\hline Father's music-related engagement & 0.41 & 0.49 \\
\hline Mother's music-related engagement & 0.26 & 0.44 \\
\hline Music-related engagement of any other family member & 0.31 & 0.46 \\
\hline Compositions (per annum) & 0.77 & 1.35 \\
\hline \multirow[t]{2}{*}{ Murray's Index Score } & 12.67 & 17.16 \\
\hline & \multicolumn{2}{|c|}{ B: Birth cohort } \\
\hline Birth cohort 1750-1799 & 0.12 & 0.33 \\
\hline Birth cohort 1800-1849 & 0.33 & 0.47 \\
\hline \multirow[t]{2}{*}{ Birth cohort 1850-1899 } & 0.55 & 0.50 \\
\hline & \multicolumn{2}{|c|}{ C: Composer-years observations } \\
\hline Period 1750-1799 & 99 & - \\
\hline Period 1800-1849 & 744 & - \\
\hline Period 1850-1899 & 1655 & - \\
\hline \multirow[t]{2}{*}{ Period 1900-1989 } & 2715 & - \\
\hline & \multicolumn{2}{|c|}{ D: Birth country } \\
\hline British Isles & 0.08 & 0.27 \\
\hline France & 0.22 & 0.42 \\
\hline Germanic Countries & 0.23 & 0.42 \\
\hline Italy & 0.13 & 0.34 \\
\hline Russia & 0.12 & 0.33 \\
\hline Spain & 0.03 & 0.16 \\
\hline Eastern Europe & 0.09 & 0.28 \\
\hline Rest of Europe & 0.03 & 0.18 \\
\hline Rest of World & 0.06 & 0.13 \\
\hline \multicolumn{3}{|c|}{$\begin{array}{l}\text { SOURCES: Grove (2009), Gilder and Port (1978) and Murray (2003). } \\
\text { NOTE: The British Isles include composers from England, Scotland, Ireland and Wales. Eastern Europe } \\
\text { relates to composers born in any of the Eastern Europe countries as classified by United Nations Statistical } \\
\text { Division, with the exclusion of Russia. The Germanic Countries relate to the three German-speaking countries } \\
\text { of Germany, Austria and Switzerland. Rest of Europe covers composers from all other European countries. } \\
\text { Rest of World relates to composers that do not fit in any of the other categories. }\end{array}$} \\
\hline
\end{tabular}


Table 2. Important cities for composers.

\begin{tabular}{|c|c|c|c|c|c|c|c|}
\hline \multicolumn{2}{|c|}{$\begin{array}{c}\text { Aggregated time spent } \\
\text { during musical career (in } \\
\text { years) }\end{array}$} & \multicolumn{2}{|c|}{$\begin{array}{l}\text { Visits during musical } \\
\text { career (in composers) }\end{array}$} & \multicolumn{2}{|c|}{$\begin{array}{c}\text { Primary destination (in } \\
\text { composers) }\end{array}$} & \multicolumn{2}{|c|}{ Births (in composers) } \\
\hline Paris & 1,589 & Paris & 66 & Paris & 34 & Paris & 9 \\
\hline London & 413 & London & 39 & Vienna & 13 & Vienna & 5 \\
\hline Vienna & 365 & Vienna & 35 & London & 9 & London & 3 \\
\hline St. Petersburg & 354 & Berlin & 24 & St. Petersburg & 8 & St. Petersburg & 3 \\
\hline Berlin & 193 & New York & 23 & Moscow & 5 & Cologne & 2 \\
\hline Moscow & 150 & St. Petersburg & 20 & Berlin & 4 & Hamburg & 2 \\
\hline New York & 142 & Rome & 18 & Budapest & 3 & Venice & 2 \\
\hline Rome & 135 & Boston & 15 & Milan & 3 & Berlin & 1 \\
\hline Budapest & 111 & Moscow & 11 & Rome & 3 & Copenhagen & 1 \\
\hline Milan & 106 & Milan & 10 & Copenhagen & 2 & Leipzig & 1 \\
\hline Venice & 92 & Prague & 10 & Leipzig & 2 & Naples & 1 \\
\hline Copenhagen & 91 & Venice & 9 & Venice & 2 & Prague & 1 \\
\hline Boston & 84 & Dresden & 7 & Boston & 1 & Rome & 1 \\
\hline Prague & 43 & Leipzig & 6 & Dresden & 1 & Stockholm & 1 \\
\hline Leipzig & 35 & Naples & 5 & Naples & 1 & Budapest & 0 \\
\hline Naples & 29 & Budapest & 4 & Prague & 1 & Dresden & 0 \\
\hline Dresden & 27 & Cologne & 4 & Stockholm & 1 & Madrid & 0 \\
\hline Stockholm & 27 & Copenhagen & 4 & Hamburg & 0 & Milan & 0 \\
\hline Madrid & 22 & Madrid & 3 & New York & 0 & Moscow & 0 \\
\hline Hamburg & 17 & Hamburg & 2 & St. Petersburg & 0 & New York & 0 \\
\hline
\end{tabular}

NOTE: Primary destination is defined as the location where a composer has spent the longest part of his career. 
Table 3. Summary statistics: Geographic clusters.

\begin{tabular}{|c|c|c|c|}
\hline & Paris & Vienna & Londor \\
\hline & \multicolumn{3}{|c|}{ A: All composers } \\
\hline Visits during musical career (in composers) & 66 & 35 & 39 \\
\hline $\begin{array}{l}\text { Primary destination (in composers) } \\
\text { Average time spent in cluster during musical } \\
\text { career of all composers (in years) }\end{array}$ & $\begin{array}{c}13.70 \\
(19.66)\end{array}$ & $\begin{array}{l}3.15 \\
(8.99)\end{array}$ & $\begin{array}{c}3.56 \\
(10.45\end{array}$ \\
\hline $\begin{array}{l}\text { Years spent in cluster during musical career } \\
\text { ff it was composers primary destination }\end{array}$ & $\begin{array}{r}41.06 \\
(14.38)\end{array}$ & $\begin{array}{r}25.53 \\
(12.61)\end{array}$ & $\begin{array}{l}40.75 \\
(5.54)\end{array}$ \\
\hline $\begin{array}{l}\text { Share of career spent in cluster if it was } \\
\text { composers primary destination }\end{array}$ & $\begin{array}{l}0.87 \\
(0.18)\end{array}$ & $\begin{array}{l}0.67 \\
(0.23)\end{array}$ & $\begin{array}{l}0.83 \\
(0.08)\end{array}$ \\
\hline Birthplace-cluster distance (in 1000 mile) & $\begin{array}{c}0.75 \\
(1.15)\end{array}$ & $\begin{array}{c}0.38 \\
(0.27)\end{array}$ & $\begin{array}{c}0.57 \\
(0.43)\end{array}$ \\
\hline \multirow[t]{2}{*}{ Compositions (per annum) } & $\begin{array}{c}0.63 \\
(1.10)\end{array}$ & $\begin{array}{r}1.55 \\
(2.62) \\
\end{array}$ & $\begin{array}{c}1.04 \\
(1.25) \\
\end{array}$ \\
\hline & \multicolumn{3}{|c|}{ B: Composers born in cluster } \\
\hline Births (in composers) & 9 & 5 & 3 \\
\hline Never left cluster (in composers) & 3 & 1 & 0 \\
\hline Time outside cluster (in years) & $\begin{array}{c}1.90 \\
(1.66)\end{array}$ & $\begin{array}{c}8.40 \\
(12.18)\end{array}$ & $\begin{array}{c}8.00 \\
(3.46)\end{array}$ \\
\hline
\end{tabular}

NOTE: See Table 2. 
Table 4. Birthplace-cluster distance and clustering.

Dependent Variable: Locating in cluster

\begin{tabular}{|c|c|c|}
\hline & \multicolumn{2}{|c|}{ OLS } \\
\hline & $(1)$ & $(2)$ \\
\hline & \multicolumn{2}{|c|}{ A: Cluster (Paris) } \\
\hline \multirow[t]{2}{*}{ Birthplace-Paris distance } & $-0.118^{* * *}$ & $-0.114^{* * *}$ \\
\hline & $(0.00272)$ & $(0.00273)$ \\
\hline composer-age controls & & yes \\
\hline time controls & & yes \\
\hline Observations & 4963 & 4963 \\
\hline R-squared & 0.276 & 0.306 \\
\hline \multirow[t]{2}{*}{ Cragg-Donald EV Statistic } & 189.1 & 129.6 \\
\hline & \multicolumn{2}{|c|}{$\begin{array}{l}\text { B: Cluster (Paris, Vienna, } \\
\text { London) }\end{array}$} \\
\hline \multirow[t]{2}{*}{ Birthplace-Paris distance } & $-0.0854^{* * *}$ & $-0.0815^{* * *}$ \\
\hline & $(0.00332)$ & $(0.00328)$ \\
\hline \multirow[t]{2}{*}{ Birthplace-Vienna distance } & $-0.0268^{* \star *}$ & $-0.0212^{* * *}$ \\
\hline & $(0.00388)$ & $(0.00387)$ \\
\hline \multirow[t]{2}{*}{ Birthplace-London distance } & $-0.0838^{* * *}$ & $-0.0820^{* * *}$ \\
\hline & $(0.00487)$ & $(0.00476)$ \\
\hline composer-age controls & & yes \\
\hline time controls & & yes \\
\hline Observations & 4963 & 4963 \\
\hline R-squared & 0.269 & 0.310 \\
\hline Cragg-Donald EV Statistic & 60.8 & 55.3 \\
\hline \multicolumn{3}{|c|}{$\begin{array}{l}\text { NOTE: Standard errors are reported in parentheses. The } \\
\text { birthplace-cluster distances are measured at logs. } \\
\text { Composer-specific age time trend (estimated with a } \\
\text { quadratic polynomial) and time controls (estimated with an } \\
\text { indicator function that is equal to one for each decade) are } \\
\text { not reported. }{ }^{* * *} / * * / * \text { indicate estimates that are significantly } \\
\text { different from zero at } 99 / 95 / 90 \text { percent confidence. }\end{array}$} \\
\hline
\end{tabular}


Table 5. Clustering and productivity of composers.

\begin{tabular}{|c|c|c|c|c|c|c|}
\hline & OLS & $\mathrm{FE}$ & IV & OLS & $\mathrm{FE}$ & IV \\
\hline & (1) & $(2)$ & (3) & $(4)$ & $(5)$ & (6) \\
\hline & \multicolumn{6}{|c|}{ A: Cluster (Paris) } \\
\hline \multirow[t]{2}{*}{ Cluster (Paris) } & $-0.162^{\star * *}$ & 0.0578 & 0.112 & $-0.0858^{* *}$ & -0.0204 & $0.244^{* * *}$ \\
\hline & $(0.0398)$ & $(0.0637)$ & $(0.0762)$ & $(0.0392)$ & $(0.0640)$ & $(0.0771)$ \\
\hline Composer-age controls & & & & yes & yes & yes \\
\hline Decade controls & & & & yes & yes & yes \\
\hline Composer controls & & yes & & & yes & \\
\hline Observations & 4963 & 4963 & 4963 & 4963 & 4963 & 4963 \\
\hline R-squared & 0.003 & 0.000 & 0.001 & 0.097 & 0.041 & 0.084 \\
\hline \multirow[t]{2}{*}{ Cragg-Donald EV Statistic } & \multicolumn{5}{|c|}{189.1} & 129.6 \\
\hline & \multicolumn{6}{|c|}{ B: Cluster (Paris, Vienna, London) } \\
\hline \multirow[t]{2}{*}{ Cluster (Paris, Vienna, London) } & $0.152^{* * *}$ & $0.0980^{*}$ & $0.229^{* * *}$ & $0.190^{* * *}$ & 0.0721 & $0.372^{* * *}$ \\
\hline & $(0.0371)$ & $(0.0511)$ & $(0.0715)$ & $(0.0367)$ & $(0.0514)$ & $(0.0732)$ \\
\hline Composer-age controls & & & & yes & yes & yes \\
\hline Decade controls & & & & yes & yes & yes \\
\hline Composer controls & & yes & & & yes & \\
\hline Observations & 4963 & 4963 & 4963 & 4963 & 4963 & 4963 \\
\hline R-squared & 0.003 & 0.001 & 0.003 & 0.101 & 0.041 & 0.097 \\
\hline Cragg-Donald EV Statistic & & & 60.8 & & & 55.3 \\
\hline
\end{tabular}


Table 6. Heterogeneity in returns.

\begin{tabular}{|c|c|c|c|c|c|}
\hline \multirow[t]{3}{*}{$\begin{array}{l}\text { EXPLANATORY } \\
\text { VARIABLES }\end{array}$} & $\begin{array}{c}\text { All } \\
\text { Composers }\end{array}$ & $\begin{array}{c}\text { Top 10 } \\
\text { composers }\end{array}$ & $\begin{array}{l}\text { All remaining } \\
\text { composers }\end{array}$ & $\begin{array}{l}\text { Worst } 16 \\
\text { composers }\end{array}$ & $\begin{array}{c}\text { Migrant } \\
\text { Composers }\end{array}$ \\
\hline & (1) & (2) & (3) & (4) & (5) \\
\hline & IV & IV & IV & IV & IV \\
\hline \multirow{3}{*}{ Cluster (Paris) } & \multicolumn{5}{|c|}{ A: Cluster (Paris) } \\
\hline & $0.244^{* * *}$ & $0.799^{*}$ & $0.166^{* * *}$ & -0.187 & $0.438^{* * *}$ \\
\hline & $(0.0771)$ & $(0.408)$ & $(0.0638)$ & $(0.118)$ & $(0.135)$ \\
\hline Composer-age controls & yes & yes & yes & yes & yes \\
\hline Decade controls & yes & yes & yes & yes & yes \\
\hline Composers & 116 & 10 & 106 & 16 & 106 \\
\hline Observations & 4963 & 379 & 4584 & 736 & 4548 \\
\hline R-squared & 0.084 & 0.600 & 0.067 & 0.195 & 0.063 \\
\hline \multirow[t]{2}{*}{ Cragg-Donald EV Statistic } & 129.6 & 22.8 & 158.6 & 20.6 & 50.8 \\
\hline & \multicolumn{5}{|c|}{ B: Cluster (Paris, Vienna, London) } \\
\hline \multirow{2}{*}{$\begin{array}{l}\text { Cluster (Paris, Vienna, } \\
\text { London) }\end{array}$} & $0.372^{* * *}$ & $1.524^{* *}$ & $0.271^{* * *}$ & $0.174^{*}$ & $0.278^{* * *}$ \\
\hline & $(0.0732)$ & $(0.703)$ & $(0.0601)$ & $(0.0899)$ & $(0.0944)$ \\
\hline Composer-age controls & yes & yes & yes & yes & yes \\
\hline Decade controls & yes & yes & yes & yes & yes \\
\hline Composers & 116 & 10 & 106 & 16 & 98 \\
\hline Observations & 4963 & 379 & 4584 & 736 & 4223 \\
\hline R-squared & 0.097 & 0.590 & 0.073 & 0.151 & 0.102 \\
\hline Cragg-Donald EV Statistic & 55.3 & 18.9 & 52.4 & 12.4 & 34.5 \\
\hline
\end{tabular}




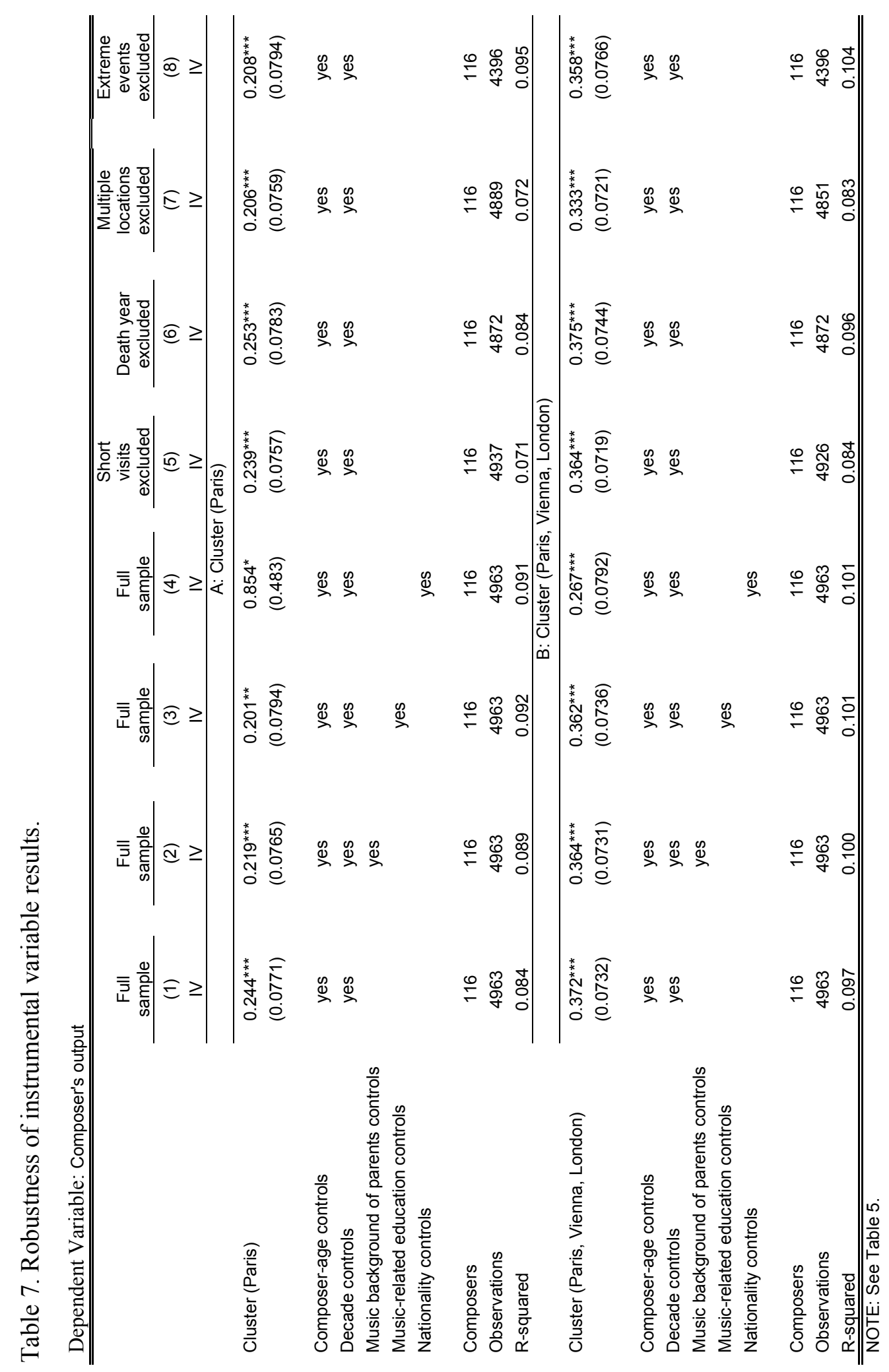


Table 8. Placebo tests: Large cities and historical clusters.

\begin{tabular}{|c|c|c|c|c|}
\hline & (1) & $(2)$ & (3) & (4) \\
\hline & OLS & IV & OLS & IV \\
\hline \multirow[t]{2}{*}{ Large non-cluster cities } & -0.0497 & $-0.354^{* * *}$ & & \\
\hline & $(0.0675)$ & $(0.130)$ & & \\
\hline \multirow[t]{2}{*}{ Historical Italian clusters } & & & -0.0864 & $-0.468^{* * *}$ \\
\hline & & & $(0.0664)$ & $(0.176)$ \\
\hline Composer-age controls & yes & yes & yes & yes \\
\hline Decade controls & yes & yes & yes & yes \\
\hline Observations & 4963 & 4963 & 4963 & 4963 \\
\hline R-squared & 0.096 & 0.093 & 0.097 & 0.091 \\
\hline Cragg-Donald EV Statistic & & 23.1 & & 17.5 \\
\hline \multicolumn{5}{|c|}{$\begin{array}{l}\text { NOTE: Standard errors are reported in parentheses. Composer-specific age time trend } \\
\text { (estimated with a quadratic polynomial) and time controls (estimated with an indicator } \\
\text { function that is equal to one for each decade) are not reported. The 'Large non-cluster } \\
\text { cities' variable aggregates the observations for Amsterdam, Copenhagen, Hamburg, } \\
\text { Madrid, Milan, Naples, Palermo and Venice. The 'Historical Italian clusters' variable } \\
\text { aggregates the observations for Bologna, Florence, Milan, Naples, Rome and Venice'. As } \\
\text { instrumental variables the respective logged distance terms between composers' birthplace } \\
\text { and each city is employed. }{ }^{* * / * / *} /{ }^{*} \text { indicate estimates that are significantly different from } \\
\text { zero at } 99 / 95 / 90 \text { percent confidence. }\end{array}$} \\
\hline
\end{tabular}


Table 9. Composers' lifetime accomplishments.

Dependent Variable: Murray's Index Score

\begin{tabular}{|c|c|c|c|c|}
\hline & Full sample & Full sample & Full sample & Full sample \\
\hline & (1) & $(2)$ & (3) & (4) \\
\hline & OLS & IV & OLS & IV \\
\hline & \multicolumn{4}{|c|}{ A: Cluster (Paris) } \\
\hline \multirow[t]{2}{*}{ Total time spent in cluster (in years) } & -0.0888 & $0.239^{*}$ & & \\
\hline & $(0.0677)$ & $(0.127)$ & & \\
\hline \multirow[t]{2}{*}{ Primary destination (binary) } & & & -4.408 & $9.521^{* *}$ \\
\hline & & & $(3.190)$ & $(4.557)$ \\
\hline Life duration controls & yes & yes & yes & yes \\
\hline Birth cohort controls & yes & yes & yes & yes \\
\hline Composers & 116 & 116 & 116 & 116 \\
\hline Observations & 116 & 116 & 116 & 116 \\
\hline R-squared & 0.157 & 0.027 & 0.161 & 0.030 \\
\hline \multirow[t]{2}{*}{ Cragg-Donald EV Statistic } & & 3.88 & & 3.43 \\
\hline & \multicolumn{4}{|c|}{ B: Cluster (Vienna) } \\
\hline \multirow[t]{2}{*}{ Total time spent in Cluster (in years) } & $0.600^{*}$ & $1.469^{* * *}$ & & \\
\hline & $(0.309)$ & $(0.491)$ & & \\
\hline \multirow[t]{2}{*}{ Primary destination (binary) } & & & $20.45^{\star * \star}$ & $38.34^{* * *}$ \\
\hline & & & $(7.141)$ & $(10.75)$ \\
\hline Life duration controls & yes & yes & yes & yes \\
\hline Time controls & yes & yes & yes & yes \\
\hline Composers & 116 & 116 & 116 & 116 \\
\hline Observations & 116 & 116 & 116 & 116 \\
\hline R-squared & 0.245 & 0.041 & 0.279 & 0.179 \\
\hline \multirow[t]{2}{*}{ Cragg-Donald EV Statistic } & & 1.18 & & 2.83 \\
\hline & \multicolumn{4}{|c|}{ C: Cluster (London) } \\
\hline \multirow[t]{2}{*}{ Total time spent in cluster (in years) } & $-0.124^{*}$ & $0.563^{*}$ & & \\
\hline & $(0.0677)$ & $(0.315)$ & & \\
\hline \multirow[t]{2}{*}{ Primary destination (binary) } & & & $-5.465^{\star *}$ & $24.69^{*}$ \\
\hline & & & $(2.512)$ & $(14.31)$ \\
\hline Life duration controls & yes & yes & yes & yes \\
\hline Birth cohort controls & yes & yes & yes & yes \\
\hline Composers & 116 & 116 & 116 & 116 \\
\hline Observations & 116 & 116 & 116 & 116 \\
\hline R-squared & 0.153 & . & 0.154 & . \\
\hline Cragg-Donald EV Statistic & & 2.27 & & 1.65 \\
\hline
\end{tabular}




\section{Figures}

Figure 1. Importance of geographic clusters.
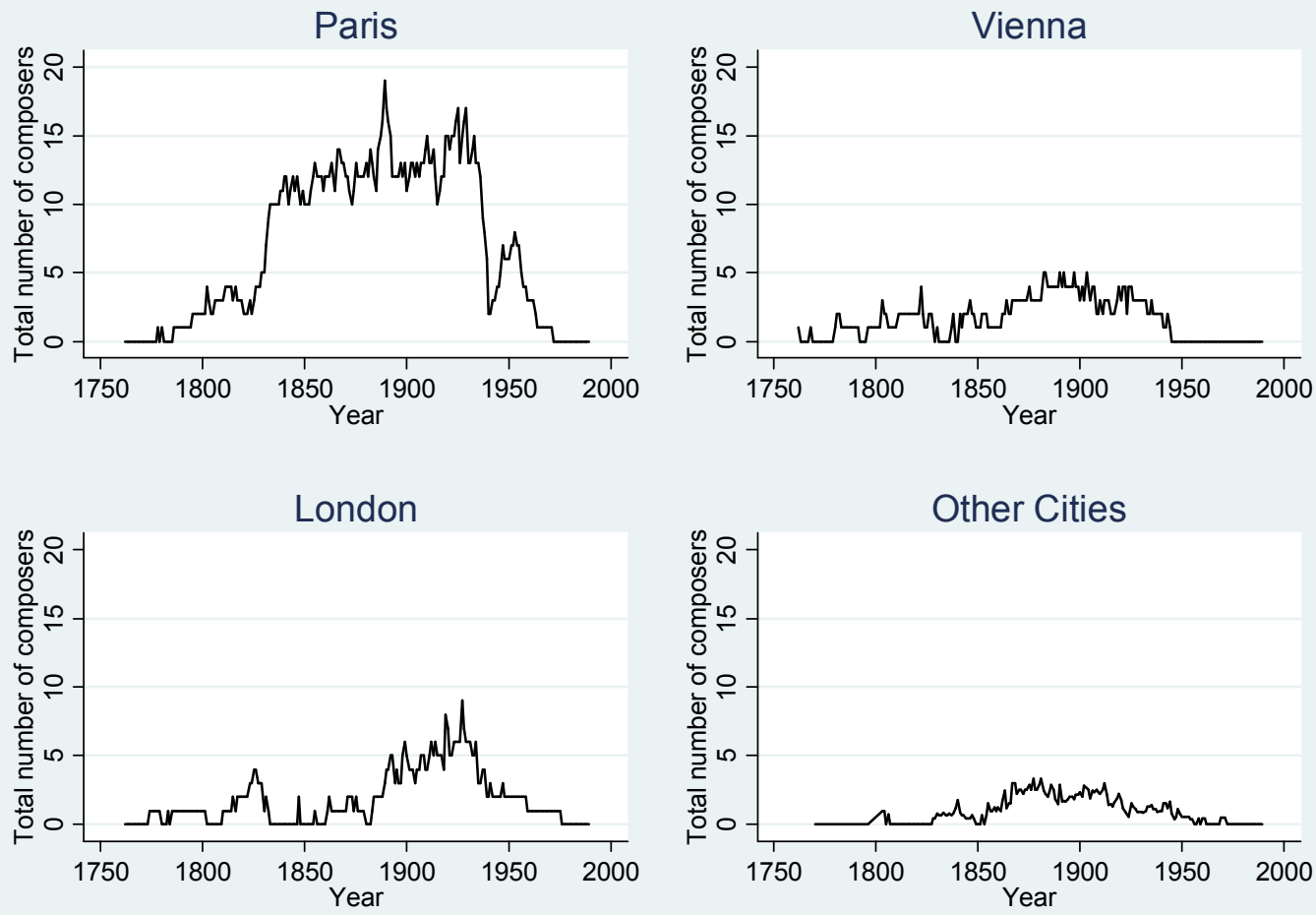

NOTE: The panel with 'Other Cities' depicts the composer count for the ten largest cities after Paris, Vienna and London, deciding upon 'Aggregated time spent during musical career' criterion (i.e. St. Petersburg, Berlin, Moscow, New York, Rome, Budapest, Milan, Venice, Copenhagen and Boston). 
Figure 2. Birthplace-cluster distance and clustering.
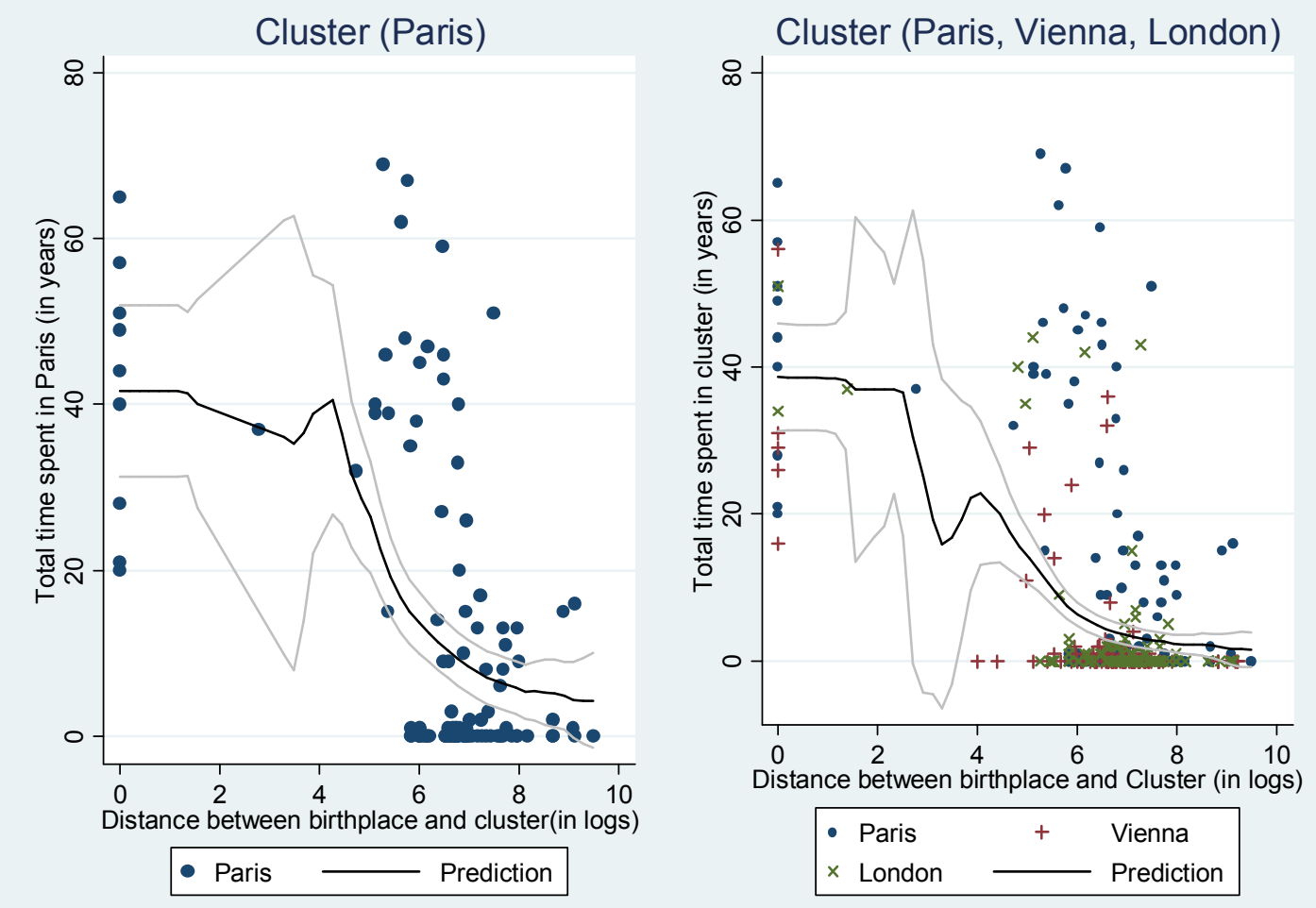

NOTE: The depicted prediction is based on a local polynomial regression method with an Epanechnikov kernel and it is presented along with a $95 \%$-confidence interval. 


\section{Appendix}

Table A1. Composers included in this study.

(Table A1 - NOT FOR PUBLICATION)

\begin{tabular}{|c|c|c|c|c|c|c|c|c|}
\hline Name & $\begin{array}{c}\text { Year } \\
\text { of } \\
\text { Birth }\end{array}$ & $\begin{array}{c}\text { Year } \\
\text { of } \\
\text { Death }\end{array}$ & $\begin{array}{c}\text { Country of } \\
\text { Birth }\end{array}$ & $\begin{array}{c}\text { Total works } \\
\text { during } \\
\text { lifetime } \\
\end{array}$ & $\begin{array}{c}\text { Murray's } \\
\text { Index } \\
\text { Score } \\
\end{array}$ & $\begin{array}{c}\text { Total } \\
\text { years in } \\
\text { Paris } \\
\end{array}$ & $\begin{array}{c}\text { Total } \\
\text { years in } \\
\text { Vienna } \\
\end{array}$ & $\begin{array}{c}\text { Total } \\
\text { years in } \\
\text { London }\end{array}$ \\
\hline Adam, Adolphe & 1803 & 1856 & France & 8 & 3 & 28 & 0 & 2 \\
\hline Albeniz, Isaac & 1860 & 1909 & Spain & 6 & 4 & 1 & 0 & 5 \\
\hline Arensky, Anton Stepanovich & 1861 & 1906 & Russia & 3 & 1 & 0 & 0 & 0 \\
\hline Auber, Daniel-Francois-Esprit & 1782 & 1871 & France & 7 & 5 & 69 & 0 & 0 \\
\hline Balakirev, Mily Alekseyevich & 1836 & 1910 & Russia & 17 & 6 & 0 & 0 & 0 \\
\hline Bartok, Bela & 1881 & 1945 & Hungary & 55 & 18 & 2 & 2 & 0 \\
\hline Bax, Sir Arnold & 1883 & 1953 & England & 86 & 3 & 0 & 0 & 37 \\
\hline Beethoven, Ludwig van & 1770 & 1827 & Germany & 223 & 100 & 0 & 32 & 0 \\
\hline Bellini, Vincenzo & 1801 & 1835 & Italy & 9 & 9 & 3 & 0 & 0 \\
\hline Berg, Alban & 1885 & 1935 & Austria & 14 & 14 & 0 & 31 & 0 \\
\hline Berlioz, Hector & 1803 & 1869 & France & 26 & 41 & 35 & 0 & 1 \\
\hline Berwald, Franz Adolf & 1796 & 1868 & Sweden & 20 & 2 & 0 & 4 & 0 \\
\hline Bizet, Georges & 1838 & 1875 & France & 20 & 10 & 21 & 0 & 0 \\
\hline Bliss, Sir Arthur & 1891 & 1975 & England & 69 & 2 & 0 & 0 & 51 \\
\hline Bloch, Ernest & 1880 & 1959 & Switzerland & 49 & 3 & 1 & 0 & 2 \\
\hline Boieldieu, Francois Adrien & 1775 & 1834 & France & 6 & 5 & 32 & 0 & 0 \\
\hline Borodin, Aleksandr & 1833 & 1887 & Russia & 11 & 8 & 0 & 0 & 0 \\
\hline Brahms, Johannes & 1833 & 1897 & Germany & 99 & 35 & 0 & 36 & 0 \\
\hline Bruch, Max & 1838 & 1920 & Germany & 17 & 2 & 0 & 0 & 0 \\
\hline Bruckner, Anton & 1824 & 1896 & Austria & 24 & 19 & 0 & 29 & 0 \\
\hline Busoni, Ferruccio & 1866 & 1924 & Italy & 29 & 8 & 0 & 1 & 0 \\
\hline Casella, Alfredo & 1883 & 1947 & Italy & 43 & 4 & 14 & 0 & 0 \\
\hline Chabrier, Emmanuel & 1841 & 1894 & France & 10 & 5 & 38 & 0 & 0 \\
\hline Charpentier, Gustave & 1860 & 1956 & France & 7 & 2 & 67 & 0 & 0 \\
\hline Chausson, Ernest & 1855 & 1899 & France & 17 & 3 & 20 & 0 & 0 \\
\hline Chavez, Carlos & 1899 & 1978 & Mexico & 43 & 2 & 0 & 0 & 0 \\
\hline Cherubini, Luigi & 1760 & 1842 & Italy & 14 & 10 & 40 & 2 & 15 \\
\hline Chopin, Fryderyk Franciszek & 1810 & 1849 & Poland & 63 & 32 & 17 & 1 & 0 \\
\hline Clementi, Muzio & 1752 & 1832 & Italy & 0 & 5 & 2 & 2 & 43 \\
\hline $\begin{array}{l}\text { Cui, Cesar } \\
\text { Dargomizhsky, Aleksandr }\end{array}$ & 1835 & 1918 & Russia & 18 & 3 & 0 & 0 & 0 \\
\hline Sergeyevich & 1813 & 1869 & Russia & 4 & 3 & 0 & 0 & 0 \\
\hline Debussy, Claude & 1862 & 1918 & France & 81 & 45 & 37 & 2 & 1 \\
\hline Delibes, Leo & 1836 & 1891 & France & 5 & 2 & 39 & 0 & 0 \\
\hline Delius, Frederick & 1862 & 1934 & England & 31 & 7 & 27 & 0 & 9 \\
\hline Dohnanyi, Ernst von & 1877 & 1960 & Hungary & 24 & 2 & 0 & 0 & 7 \\
\hline Donizetti, Gaetano & 1797 & 1848 & Italy & 11 & 9 & 9 & 0 & 0 \\
\hline Dukas, Paul & 1865 & 1935 & France & 17 & 4 & 49 & 0 & 1 \\
\hline Dvorak, Antonin & 1841 & 1904 & Czech & 89 & 13 & 0 & 1 & 2 \\
\hline Elgar, Edward & 1857 & 1934 & England & 54 & 8 & 0 & 0 & 44 \\
\hline Enesco, Georges & 1881 & 1955 & Romania & 19 & 2 & 51 & 0 & 0 \\
\hline Falla, Manuel de & 1876 & 1946 & Spain & 14 & 9 & 8 & 0 & 2 \\
\hline Faure, Gabriel & 1845 & 1924 & France & 56 & 13 & 59 & 0 & 0 \\
\hline Field, John & 1782 & 1837 & Ireland & 2 & 3 & 1 & 1 & 1 \\
\hline Flotow, Friedrich Freiherr von & 1812 & 1883 & Germany & 1 & 2 & 20 & 3 & 0 \\
\hline Franck, Cesar & 1822 & 1890 & France & 31 & 15 & 48 & 0 & 0 \\
\hline Gade, Niels Wilhelm & 1817 & 1890 & Denmark & 33 & 3 & 0 & 0 & 0 \\
\hline Gerhard, Roberto & 1896 & 1970 & Spain & 30 & 1 & 0 & 0 & 0 \\
\hline
\end{tabular}




\begin{tabular}{|c|c|c|c|c|c|c|c|c|}
\hline $\begin{array}{l}\text { Gershwin, George } \\
\text { Glazunov, Aleksandr }\end{array}$ & 1898 & 1937 & USA & 7 & 6 & 0 & 0 & 0 \\
\hline Konstantinovich & 1865 & 1936 & Russia & 41 & 4 & 8 & 0 & 3 \\
\hline Glier, Reingol'd Moritsevich & 1875 & 1956 & Russia & 21 & 1 & 0 & 0 & 0 \\
\hline Glinka, Mikhail Ivanovich & 1804 & 1857 & Russia & 13 & 8 & 9 & 0 & 0 \\
\hline Gounod, Charles-Francois & 1818 & 1893 & France & 22 & 13 & 51 & 0 & 3 \\
\hline Grieg, Edvard Hagerup & 1843 & 1907 & Norway & 21 & 11 & 0 & 0 & 0 \\
\hline Harris, Roy & 1898 & 1979 & USA & 66 & 3 & 1 & 0 & 0 \\
\hline Hindemith, Paul & 1895 & 1963 & Germany & 60 & 19 & 0 & 0 & 1 \\
\hline Holst, Gustav & 1874 & 1934 & England & 75 & 5 & 0 & 0 & 35 \\
\hline Honegger, Arthur & 1892 & 1955 & France & 41 & 9 & 40 & 0 & 0 \\
\hline Humperdinck, Engelbert & 1854 & 1921 & Germany & 10 & 3 & 1 & 1 & 1 \\
\hline Ibert, Jacques & 1890 & 1962 & France & 21 & 2 & 40 & 0 & 0 \\
\hline Indy, Vincent d' & 1851 & 1931 & France & 43 & 9 & 57 & 0 & 0 \\
\hline Janacek, Leos & 1854 & 1928 & Czech & 22 & 7 & 0 & 0 & 0 \\
\hline Kodaly, Zoltan & 1882 & 1967 & Hungary & 31 & 7 & 0 & 0 & 1 \\
\hline Lalo, Edouard & 1823 & 1892 & France & 13 & 3 & 46 & 0 & 0 \\
\hline Leoncavallo, Ruggero & 1857 & 1919 & Italy & 4 & 3 & 13 & 0 & 1 \\
\hline Liszt, Franz & 1811 & 1886 & Hungary & 30 & 43 & 0 & 0 & 0 \\
\hline Mahler, Gustav & 1860 & 1911 & Austria & 18 & 23 & 0 & 11 & 0 \\
\hline Malipiero, Gian Francesco & 1882 & 1973 & Italy & 60 & 5 & 1 & 0 & 0 \\
\hline Martin, Frank & 1890 & 1974 & Switzerland & 51 & 3 & 0 & 0 & 0 \\
\hline Martinu, Bohuslav & 1890 & 1959 & Czech & 54 & 3 & 15 & 0 & 1 \\
\hline $\begin{array}{l}\text { Mascagni, Pietro } \\
\text { Massenet, Jules Emile }\end{array}$ & 1863 & 1945 & Italy & 22 & 3 & 1 & 1 & 1 \\
\hline Frederic & 1842 & 1912 & France & 32 & 9 & 47 & 0 & 0 \\
\hline Mendelssohn, Felix & 1809 & 1847 & Germany & 90 & 30 & 0 & 0 & 2 \\
\hline Meyerbeer, Giacomo & 1791 & 1864 & Germany & 6 & 14 & 33 & 0 & 0 \\
\hline Milhaud, Darius & 1892 & 1974 & France & 85 & 13 & 46 & 1 & 1 \\
\hline Mozart, Wolfgang Amadeus & 1756 & 1791 & Austria & 237 & 100 & 1 & 14 & 0 \\
\hline Musorgsky, Modeste Petrovich & 1839 & 1881 & Russia & 25 & 16 & 0 & 0 & 0 \\
\hline Nicolai, Otto & 1810 & 1849 & Germany & 11 & 2 & 0 & 8 & 0 \\
\hline Nielsen, Carl & 1865 & 1931 & Denmark & 29 & 3 & 1 & 0 & 0 \\
\hline Offenbach, Jacques & 1819 & 1880 & Germany & 8 & 6 & 45 & 1 & 0 \\
\hline Orff, Carl & 1895 & 1982 & Germany & 21 & 5 & 0 & 0 & 0 \\
\hline Piston, Walter & 1894 & 1976 & USA & 60 & 2 & 2 & 0 & 0 \\
\hline Poulenc, Francis & 1899 & 1963 & France & 97 & 8 & 44 & 1 & 0 \\
\hline Prokofiev, Sergey & 1891 & 1953 & Russia & 82 & 12 & 11 & 0 & 5 \\
\hline Puccini, Giacomo & 1858 & 1924 & Italy & 10 & 10 & 0 & 0 & 0 \\
\hline Rachmaninoff, Serge & 1873 & 1943 & Russia & 44 & 7 & 13 & 0 & 1 \\
\hline Ravel, Maurice & 1875 & 1937 & France & 36 & 23 & 43 & 0 & 0 \\
\hline Reger, Max & 1873 & 1916 & Germany & 54 & 7 & 0 & 0 & 0 \\
\hline $\begin{array}{l}\text { Respighi, Ottorino } \\
\text { Rimsky-Korsakov, Nikolay }\end{array}$ & 1879 & 1936 & Italy & 46 & 3 & 0 & 0 & 0 \\
\hline Andreyevich & 1844 & 1908 & Russia & 35 & 15 & 1 & 0 & 0 \\
\hline Rossini, Gioachino & 1792 & 1868 & Italy & 22 & 22 & 10 & 1 & 6 \\
\hline Roussel, Albert & 1869 & 1937 & France & 23 & 5 & 15 & 0 & 0 \\
\hline Saint-Saens, Camille & 1835 & 1920 & France & 40 & 13 & 65 & 0 & 0 \\
\hline Satie, Erik & 1866 & 1925 & $\begin{array}{l}\text { France } \\
\text { Austria- }\end{array}$ & 46 & 7 & 39 & 0 & 0 \\
\hline Schoenberg, Arnold & 1874 & 1951 & Hungary & 29 & 39 & 0 & 26 & 1 \\
\hline Schubert, Franz & 1797 & 1828 & Austria & 74 & 44 & 0 & 16 & 0 \\
\hline Schumann, Robert & 1810 & 1856 & Germany & 46 & 42 & 0 & 1 & 0 \\
\hline Sessions, Roger & 1896 & 1985 & USA & 31 & 4 & 0 & 0 & 0 \\
\hline Sibelius, Jean & 1865 & 1957 & Finnland & 54 & 10 & 0 & 1 & 0 \\
\hline Spontini, Gaspare & 1774 & 1851 & Italy & 5 & 6 & 26 & 0 & 0 \\
\hline
\end{tabular}




\begin{tabular}{lcccccccc} 
Stanford, Sir Charles Villiers & 1852 & 1924 & Britain & 29 & 3 & 0 & 0 & 42 \\
Strauss, Johann (Jr.) & 1825 & 1899 & Austria & 8 & 5 & 0 & 56 & 0 \\
Strauss, Richard & 1864 & 1949 & Germany & 44 & 26 & 0 & 24 & 2 \\
Stravinsky, Igor & 1882 & 1971 & Russia & 66 & 45 & 13 & 0 & 2 \\
Sullivan, Sir Arthur & 1842 & 1900 & England & 35 & 5 & 1 & 1 & 34 \\
Szymanowski, Karol & 1882 & 1937 & Poland & 13 & 4 & 6 & 1 & 0 \\
Tchaikovsky, Pyotr Il'yich & 1840 & 1893 & Russia & 35 & 20 & 0 & 0 & 0 \\
Thomas, Ambroise & 1811 & 1896 & France & 26 & 3 & 62 & 0 & 0 \\
Thomson, Virgil & 1896 & 1989 & USA & 42 & 3 & 15 & 0 & 0 \\
Vaughan Williams, Ralph & 1872 & 1958 & England & 83 & 9 & 0 & 0 & 40 \\
Verdi, Giuseppe & 1813 & 1901 & Italy & 28 & 30 & 9 & 2 & 3 \\
Villa-Lobos, Heitor & 1887 & 1959 & Brazil & 83 & 4 & 16 & 0 & 0 \\
Wagner, Richard & 1813 & 1883 & Germany & 15 & 79 & 3 & 0 & 2 \\
Weber, Carl Maria von & 1786 & 1826 & Germany & 22 & 27 & 0 & 2 & 2 \\
Webern, Anton & 1883 & 1945 & Austria & 28 & 19 & 1 & 29 & 0 \\
Wolf, Hugo & 1860 & 1903 & Austria & 13 & 11 & 0 & 20 & 0 \\
Wolf-Ferrari, Ermanno & 1876 & 1948 & Italy & 14 & 2 & 0 & 0 \\
\hline \hline
\end{tabular}

SOURCE: Data on composers are obtained from Grove Music Online (2009). Number of important compositions is taken from Gilder and Port (1978). 
Table A2. Clustering and parental background.

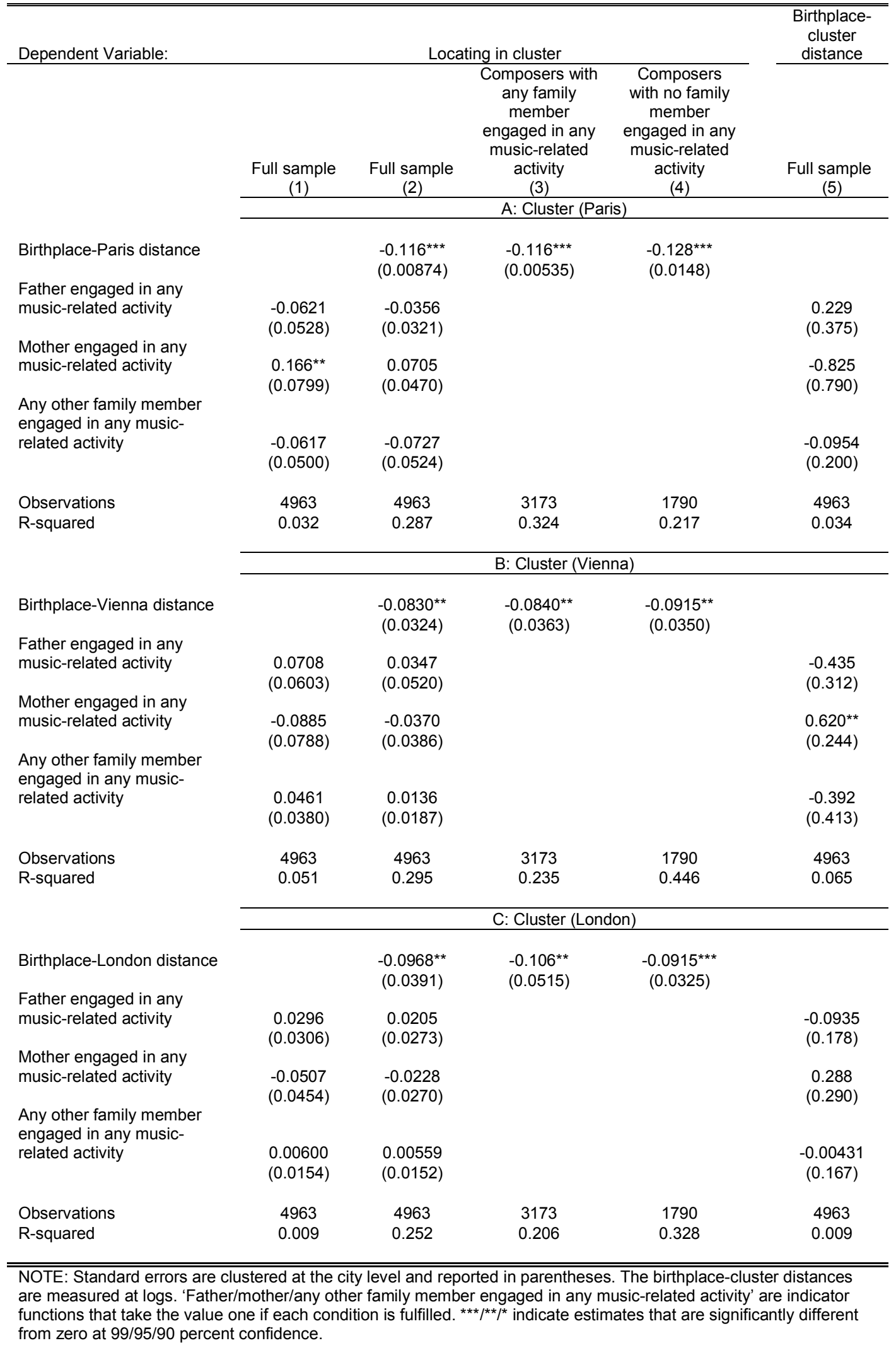




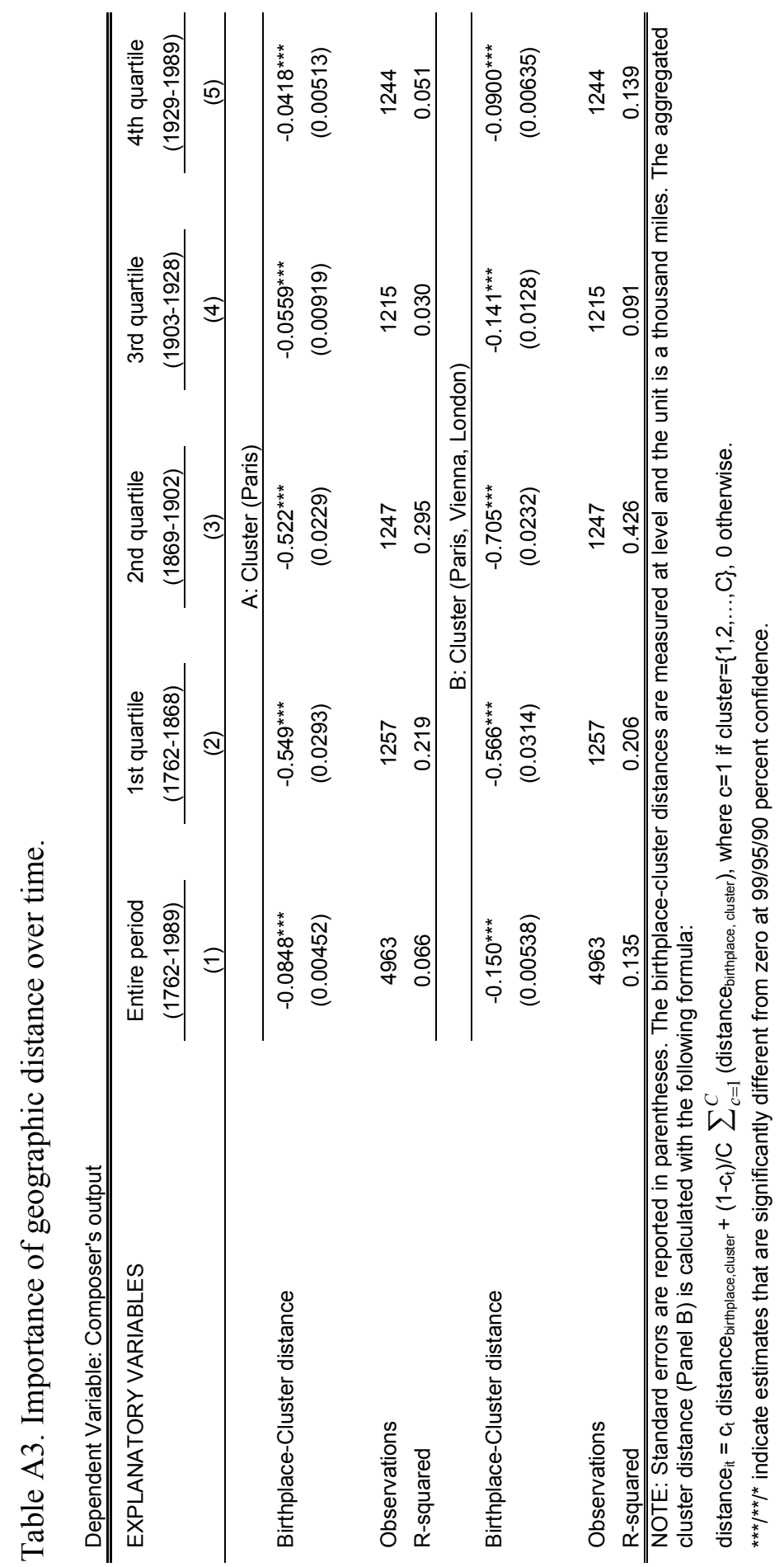


Table A4. Clustering and productivity using time-varying instrumental variables.

\begin{tabular}{|c|c|c|c|c|}
\hline & \multicolumn{2}{|c|}{ Full sample } & \multicolumn{2}{|c|}{ Full sample } \\
\hline & (1) & $(2)$ & (3) & $(4)$ \\
\hline & First-stage & Second-stage & First-stage & Second-stage \\
\hline & Cluster & Output & Cluster & Output \\
\hline & \multicolumn{4}{|c|}{ A: Cluster (Paris) } \\
\hline \multirow[t]{2}{*}{ Cluster(Paris) } & & $0.220^{\star * *}$ & & $0.247^{* * *}$ \\
\hline & & $(0.0735)$ & & $(0.0813)$ \\
\hline \multirow[t]{2}{*}{$(\text { Birthplace-Paris distance })^{*}($ composers' age) } & $-0.00219^{* * *}$ & & & \\
\hline & $(5.47 e-05)$ & & & \\
\hline \multirow[t]{2}{*}{ (Birthplace-Paris distance $)^{\star}($ Intra-state war) } & & & $-0.0240^{* * *}$ & \\
\hline & & & $(0.00548)$ & \\
\hline Composer-age controls & yes & yes & yes & yes \\
\hline Decade controls & yes & yes & yes & yes \\
\hline Composers & 116 & 116 & 115 & 115 \\
\hline Observations & 4963 & 4963 & 4868 & 4868 \\
\hline \multirow[t]{2}{*}{ Cragg-Donald EV Statistic } & & 159.4 & & 19.2 \\
\hline & \multicolumn{4}{|c|}{ B: Cluster (Paris, Vienna, London) } \\
\hline \multirow[t]{2}{*}{ Cluster(Paris, Vienna, London) } & & $0.233^{* * *}$ & & $0.153^{* * *}$ \\
\hline & & $(0.0771)$ & & $(0.0406)$ \\
\hline \multirow[t]{2}{*}{$(\text { Birthplace-Paris distance })^{\star}($ composers' age) } & $-0.00207^{* * *}$ & & & \\
\hline & $(6.07 e-05)$ & & & \\
\hline \multirow[t]{2}{*}{ (Birthplace-Paris distance $)^{\star}($ Intra-state war) } & & & $-0.0388^{* * *}$ & \\
\hline & & & $(0.00582)$ & \\
\hline Composer-age controls & yes & yes & yes & yes \\
\hline Decade controls & yes & yes & yes & yes \\
\hline Composers & 116 & 116 & 115 & 115 \\
\hline Observations & 4963 & 4963 & 4868 & 4868 \\
\hline Cragg-Donald EV Statistic & & 115.7 & & 44.4 \\
\hline \multicolumn{5}{|c|}{$\begin{array}{l}\text { NOTE: Standard errors are reported in parentheses. The second-stage regression presented in column (2) uses ar } \\
\text { interaction term between Birthplace-Paris distance and composers' age as an instrumental variable. The second-stag } \\
\text { regression presented in column (4) uses an interaction term between Birthplace-Paris distance and the incidence o } \\
\text { intra-state war as an instrumental variable. Composer-specific age time trend (estimated with a quadratic polynomial } \\
\text { and time controls (estimated with an indicator function that is equal to one for each decade) are not reported. }{ }^{* * * /{ }^{* *} /} \\
\text { indicate estimates that are significantly different from zero at } 99 / 95 / 90 \text { percent confidence. }\end{array}$} \\
\hline
\end{tabular}

